\title{
Phosphorus supply affects seedling growth of mycorrhizal but not cluster-root forming jarrah-forest species
}

\author{
Rachel J. Standish $(\mathbb{D} \cdot$ Matthew I. Daws $(\mathbb{D} \cdot$ \\ Tim K. Morald · Jane Speijers • John M. Koch • \\ Richard J. Hobbs ${ }^{(1)} \cdot$ Mark Tibbett ${ }^{(1)}$
}

Received: 30 April 2021 / Accepted: 9 December 2021 / Published online: 31 January 2022

(C) The Author(s) 2022

\begin{abstract}
Aims Fertiliser is often used to kick-start ecological restoration despite growing evidence of the potentially negative impacts on plant diversity. Jarrah (Eucalyptus marginata) forest species growing on nutrient (especially phosphorus) impoverished soils in southwestern Australia have a suite of adaptations for phosphorus (P) acquisition, including the formation of cluster roots, and associations with mycorrhizal fungi. Here we investigated how escalating $\mathrm{P}$ supply, along with a stoichiometric adjustment of nitrogen $(\mathrm{N})$ supply, impacted the growth and nutrition of a wide range of jarrah forest seedlings.
\end{abstract}

Responsible Editor: Stefano Cesco.

Supplementary Information The online version contains supplementary material available at https://doi. org/10.1007/s11104-021-05268-2.

\section{R. J. Standish}

Harry Butler Institute, Murdoch University, 90 South

Street, Murdoch, Western Australia 6150, Australia

M. I. Daws · M. Tibbett $(\square)$

Department of Sustainable Land Management and Soil Research Centre, School of Agriculture Policy and Development, University of Reading, Berkshire RG6 6AR, UK

e-mail: m.tibbett@ reading.ac.uk

T. K. Morald · R. J. Hobbs · M. Tibbett

School of Biological Sciences, The University of Western

Australia, Crawley, WA 6009, Australia
Methods In a pot experiment, we measured seedling biomass and nutritional responses of 12 jarrah forest species to a gradient of $\mathrm{P}$ supply in relation to $\mathrm{N}$ supply, and for the mycorrhizal species, inoculation with arbuscular mycorrhizal fungi.

Results Three cluster-root forming species did not respond to increasing $\mathrm{P}$, probably because they were reliant on seed P. Generally, mycorrhizal species showed a positive biomass response to increasing $\mathrm{P}$ when $\mathrm{N}$ was available. Mycorrhizas benefited seedling growth at low P (9 mg P added per $\mathrm{kg}$ of jarrah forest soil) when $\mathrm{N}$ was also available, and were parasitic to seedling growth at high $\mathrm{P}$ (243 mg P/ kg soil) without additional $\mathrm{N}$.

Conclusions These results highlight importance of $\mathrm{P}$ and $\mathrm{N}$ supply in determining the nature of the symbiosis between plants and mycorrhizal fungi. Since P supply has the potential to reduce plant growth, for a

\section{J. Speijers \\ Department of Agriculture and Food, 3 Baron-Hay Court, South Perth, Western Australia 6151, Australia \\ J. M. Koch \\ Mining Environmental Department, Alcoa of Australia Ltd, PO Box 172, Pinjarra, Western Australia 6208, \\ Australia}


range of species, our results suggest careful consideration of fertiliser amounts for ecological restoration of ecosystems adapted to nutrient poor soils.

Keywords Arbuscular mycorrhizal fungi · Ecological restoration - Mycorrhizal growth dependency $\cdot \mathrm{N}$ and $\mathrm{P}$ co-limitation $\cdot$ Plant-soil interactions $\cdot$ Pot experiment

\section{Introduction}

Ecological restoration is required to meet global biodiversity conservation goals (United Nations Sustainable Development Goals 2015). Ecosystems degraded by human activity pose a significant challenge for ecological restoration especially where degraded soils impact establishment of native vegetation (Bradshaw 1997). Fertiliser is prescribed for ecological restoration where there is insufficient quantity or availability of soil nutrients (Whisenant 1999). Consequently, the application of fertiliser is considered necessary, to replace nutrients lost in vegetation and soils, and best practice, to kickstart restoration of native plants and ecosystems after surface mining in Brazil, Canada, and Australia (Bizuti et al. 2020; Pinno et al. 2012; Tibbett 2010). Yet, in other restoration contexts the removal of soil nutrients is often required to kickstart restoration (e.g. abandoned farmlands, sites exposed to high atmospheric nitrogen deposition). Here, nutrient enrichment can favour some species over others and alter species composition compared with historical reference plant communities (e.g. Smits et al. 2008; Wassen et al. 2005). These latter findings suggest caution in the use of fertilisers for mine restoration.

Yet evidence from mine restoration is mixed. Fertiliser application can positively impact plant growth, especially trees, and reduce the risk of soil erosion by increasing plant cover (e.g. Ward et al. 1990). However, it can also negatively impact some plant species by increasing competition with highly nutrientresponsive species, such as non-native weeds (e.g. Daws et al. 2013; Norman et al. 2006; Nussbaumer et al. 2016). Further, in regions with highly weathered, nutrient-deficient soils, fertiliser application, particularly $\mathrm{P}$, can negatively affect establishment of some native species (Lambers et al. 2008). For example, the addition of $26 \mathrm{~kg} \mathrm{P} \mathrm{ha}^{-1}$ for restoration of
South African fynbos resulted in increased mortality of native proteaceous species three years after its application (Holmes 2001). These cluster-root forming species are sensitive to P-toxicity when supplied with $\mathrm{P}$ concentrations above those that they experience in nature (de Campos et al. 2013; Handreck 1991; Lambers et al. 2002; Pang et al. 2010; Shane et al. 2004a; Williams et al. 2019), potentially due to the loss of low affinity transporter systems (Huang et al. 2011). In south western Australia, P-fertiliser addition also decreased the abundance of slow-growing resprouter species in jarrah forest restored after mining (Daws et al. 2013; 2019a, b).

Physical, chemical, and biological components of soil, and their interactions, play important roles in ecosystem development on mined lands (Rowland et al. 2009). This is particularly true in weathered, nutrient-poor soils because of the reliance of many plants on mycorrhizal fungi to assist with nutrient acquisition, particularly $\mathrm{P}$ (Bowen 1981). As for cluster-root forming species, a range of mycorrhizal plant species adapted to grow on nutrient impoverished soils have a limited ability to regulate P-uptake when the P-supply is increased (Shane et al. 2004a). For example, the dominant tree species in the jarrah forest (jarrah, Eucalyptus marginata) exhibited visible symptoms of toxicity in the glasshouse after two pulses of $\mathrm{P}$; shoot $\mathrm{P}$ concentrations were between 1.8 and $5.5 \mathrm{mg} \mathrm{P} \mathrm{g}^{-1} \mathrm{DW}$ (Kariman et al. 2014. However, arbuscular mycorrhizal (AM) fungal associations can reduce the severity of P-toxicity in jarrah by reducing P-uptake (Kariman et al. 2014). Conversely, fertilisation with phosphate can diminish the benefits of AM associations to plants and in the extreme case, generate parasitic associations (Johnson et al. 1997; Standish et al. 2021). These studies suggest a greater understanding of fertiliser impacts on plant-soil dynamics is required for restoration of P-impoverished ecosystems.

Here, we add to growing body of research to inform best practice use of fertiliser in the ecological restoration of jarrah forest after bauxite mining in southwestern Australia. Until recently, P-fertiliser had been generously applied (up to $80 \mathrm{~kg} \mathrm{P} \mathrm{ha}^{-1}$ ) to kickstart restoration (Koch 2007) despite the inherently nutrient-impoverished soils characteristic of the reference ecosystem (Handreck 1997). The rationale for the high application rates has been to replace nutrients that are lost during the mining process 
and to promote the establishment of nitrogen-fixing legumes, assuming these species would facilitate the return of other plant species (Grant 2006; Koch 2007). While P-fertilisation has usually resulted in the restoration of jarrah forest similar in diversity to that cases legumes can dominate the early successional forest and so alter the ecosystem trajectory (Grant 2006; Norman et al. 2006). In addition, a range of slow-growing, long-lived resprouter species tend to occur at reduced abundances following the application of P (Daws et al. 2019a). This negative effect of $\mathrm{P}$ fertiliser on the abundance of slow growing species can potentially be explained by either competition with vigorous P-responsive species, such as legumes (Dell et al. 1987; Stoneman et al. 1995; Daws et al. 2019a, b), or direct negative effects of elevated $\mathrm{P}$ on growth rates and survival. Even a single initial application of fertiliser to restored sites, including the jarrah forest, can result in elevated plant-available soil phosphorus concentrations after 20 or more years (Addison et al. 2019; Banning et al. 2008; Smits et al. 2008; Spain et al. 2015). Therefore, any potential negative effects of P-addition on competitive dynamics may persist in the long-term.

In this large glasshouse study, we tested seedling responses of a range of jarrah forest species, including both AM species and non-mycorrhizal cluster-root forming species, to $\mathrm{P}$ amendment, with and without additional $\mathrm{N}$ supply, where $\mathrm{AM}$ species were grown in treatments with and without AM inoculation.

Table 1 Traits of 7 of the 12 jarrah forest plants included in this pot study. Species nomenclature follows that of the Western Australian Herbarium (1998-); life forms after Bell et al. (1993). \$ Mycorrhizal associations recorded by Brundrett and Abbott (1991). †Cluster roots recorded by Lamont (1972a) and Malajczuk and Bowen (1974). Mass (mean \pm SE; $n=10$ ) and nutrient contents per seed estimated from bulk samples. cleared for mining (Koch and Hobbs 2007), in some

Individual seedlings of each species were grown in pots in the absence of competition. Specifically, we tested the hypotheses that: (1) plant responses to $\mathrm{P}$ are dependent on species' nutrient acquisition strategy; (2) seedlings will exhibit P-sensitivity to high external $\mathrm{P}$ concentrations in the absence of mycorrhiza; (3) Mycorrhizal symbiosis will limit growth suppression at high external P concentrations; (4) $\mathrm{N}$ addition will effect species-specific $\mathrm{P}$ responses. That is, the growth responses to $\mathrm{P}$ will be dependent on the addition of $\mathrm{N}$ due to: the potential for $\mathrm{N}$ and $\mathrm{P}$ co-limitation, differential AM fungal responses to $\mathrm{N}$, differences in plant species nutrient stoichiometry, or some combination of these factors. Results are discussed in relation to plant mineral nutrition and growth and their implications for ecological restoration.

\section{Materials and methods}

\section{Experimental design}

We used a factorial design to test the effect of increasing $\mathrm{P}$ supply on seedling growth responses of 12 jarrah forest species (Table 1). Five P-levels were used: $0,9,27,81$ and $243 \mathrm{mg} \mathrm{P} \mathrm{kg}^{-1}$ of dry jarrah forest soil; these were selected to span current and previous rates of $\mathrm{P}$-fertiliser application for jarrah forest restoration after bauxite mining (i.e., 20-80 kg P ha ${ }^{-1}$; Standish et al. 2015). Jarrah forest soil is low in plant-available P and N (Standish et al.

Plants belonging to the Fabaceae and Casuarinaceae form associations with nitrogen-fixing microorganisms. Data for Acacia celastrifolia, Bossiaea aquifolium, Eucalyptus marginata, Hakea undulata and Phyllanthus calycinus is included in Standish et al. (2021) except seed N, which is $0.97 \mathrm{mg}$, $0.48 \mathrm{mg}, 0.81 \mathrm{mg}, 2.05 \mathrm{mg}$ and $0.06 \mathrm{mg}$, respectively

\begin{tabular}{|c|c|c|c|c|c|c|}
\hline Species & Family & Life form & $\mathrm{P}$ acquisition strategy & $\begin{array}{l}\text { Seed mass } \\
\text { (mg/seed) }\end{array}$ & $\begin{array}{l}\text { Seed P } \\
(\mathrm{mg} / \text { seed })\end{array}$ & $\begin{array}{l}\text { Seed } \\
\mathrm{N}(\mathrm{mg} / \\
\text { seed })\end{array}$ \\
\hline Allocasuarina fraseriana & Casuarinaceae & Tree & $\mathrm{AM} / \mathrm{ECM} \neq$ & $5 \pm 0.5$ & 0.03 & 0.19 \\
\hline Acacia pulchella & Fabaceae & Shrub & $\mathrm{AM} / \mathrm{ECM} \ddagger$ & $11 \pm 0.8$ & 0.03 & 0.55 \\
\hline Bossiaea ornata & Fabaceae & Shrub & $\mathrm{AM} \ddagger$ & $3 \pm 0.2$ & 0.01 & 0.18 \\
\hline Bossiaea pulchella & Fabaceae & Shrub & $\mathrm{AM}$ & $18 \pm 0.9$ & 0.05 & 0.70 \\
\hline Banksia grandis & Proteaceae & Small tree & Cluster roots $\dagger$ & $78 \pm 3.7$ & 0.81 & 9.99 \\
\hline Hakea prostrata & Proteaceae & Shrub & Cluster roots $\dagger$ & $44 \pm 3.2$ & 0.45 & 4.39 \\
\hline Xanthorrhoea gracilis & Xanthorrhoeaceae & Sub-shrub & $\mathrm{AM} \ddagger$ & $14 \pm 1.2$ & 0.07 & 0.57 \\
\hline
\end{tabular}




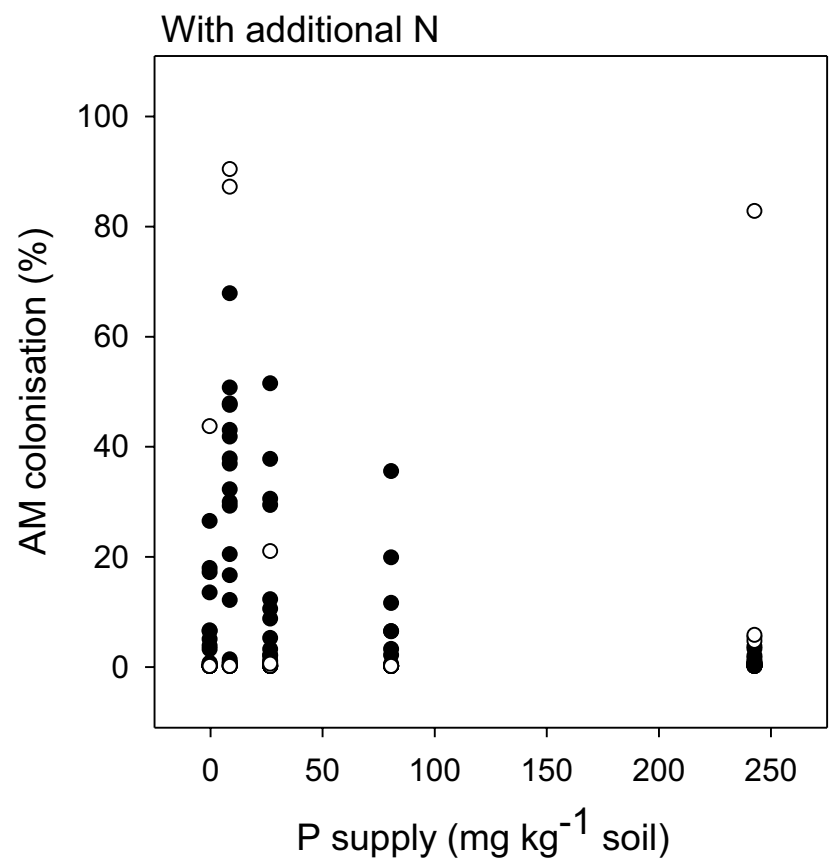

Fig. 1 Percentage colonisation of fine roots by arbuscular mycorrhizal fungi at $0,9,27,81$ and $243 \mathrm{mg}$ added $\mathrm{P}$ per $\mathrm{kg}$ dry soil, with and without additional nitrogen $(30 \mathrm{mg}$ per $\mathrm{kg}$ of soil), 14-27 weeks after seedlings were inoculated with Rhizo-

2008) and readily adsorbs phosphate (Bolan et al. 1983); the highest P-level was included to try to elicit P-toxicity. We added AM inoculum to half the pots containing plant species that form mycorrhizal associations; AM inoculum was not added to pots containing non-mycorrhizal species. The design also included $\mathrm{N}$ addition $(+\mathrm{N}) /$ no $\mathrm{N}$ addition $(-\mathrm{N})$ and there were three replicates of each treatment: in total there were 630 pots [i.e., (5 P-levels $\times 9$ mycorrhizal species $\times 2$ AM-treatments $\times 2 \mathrm{~N}$-treatments $\times 3$ replicates $)+(5$ P-levels $\times 3$ non-mycorrhizal species $\times 2$ N-treatments $\times 3$ replicates)]. Pots, each containing one native plant, were arranged in a completely randomised block design within a glasshouse.

We used topsoil (0-10 cm depth) collected from under the jarrah forest at Huntly, Western Australia $\left(32^{\circ} 35^{\prime} 06^{\prime \prime} \mathrm{S}, 116^{\circ} 06^{\prime} 44^{\prime \prime} \mathrm{E}\right)$. These soils tend to be low in available phosphorus, and nitrogen, and be slightly acidic (Table S1). Sampled soil was passed through an $8 \mathrm{~mm}$ sieve, steamed twice at $80^{\circ} \mathrm{C}$ for three hours, and dried at $100{ }^{\circ} \mathrm{C}$ to eradicate naturally occurring mycorrhizal inocula. Then, for the

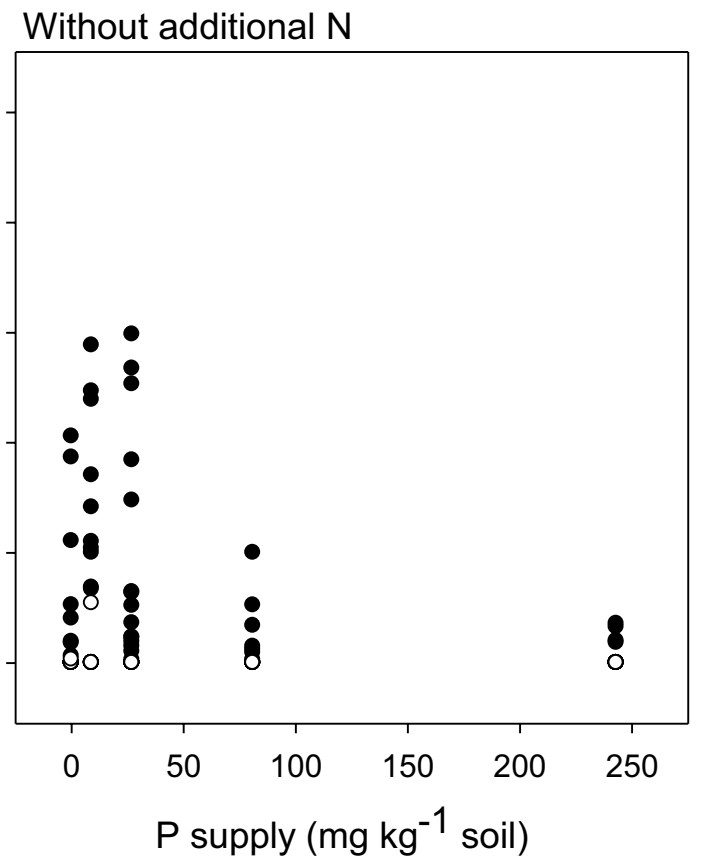

phagus irregularis; $\bigcirc=P$. calycinus and $\mathbf{O}=$ data for eight other mycorrhizal species; $n=3$ per species per N/P treatment combination

AM treatment, bulk soil portions were inoculated (1 inoculum: 9 parts soil) and $1.3 \mathrm{~kg}$ portions were poured into pots measuring $8 \mathrm{~cm} \times 8 \mathrm{~cm} \times 18 \mathrm{~cm}$ (depth). The AM inoculum consisted of Rhizophagus irregularis (Błaszk., Wubet, Renker and Buscot) C. Walker and A. Schüßler 2010 (formerly Glomus intraradices), hyphae and colonised leek (Allium porrum L.) roots, grown in sterilised river sand. Rhizophagus species are common in jarrah forest soils (Brundrett and Abbott 1994) and we selected this species for its ease of culture and ability to rapidly colonise roots of Western Australian native plants. For the treatment without AM, we added one-part sterilised river sand to nine parts soil. Species belonging to the Fabaceae usually form associations with soil micro-organisms that fix nitrogen, but the use of steamed soil meant that only a few seedlings formed root nodules.

Phosphorus was added to the pots at the time of planting, as $\mathrm{KH}_{2} \mathrm{PO}_{4}$ (Chem-Supply Pty Ltd, Gillman $\mathrm{SA}$, Australia) because it is readily available to plants. To ensure a constant ionic background and balanced potassium levels, potassium chloride $(\mathrm{KCl})$ was added 

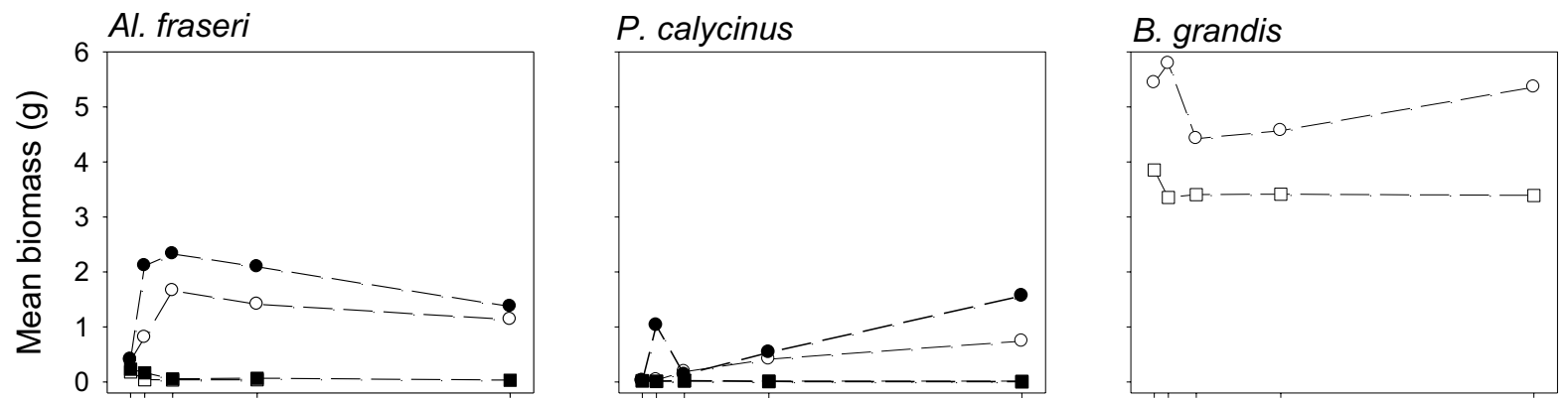

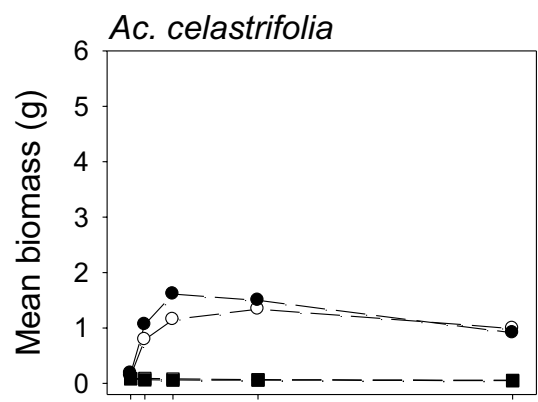

Bo. aquifolium

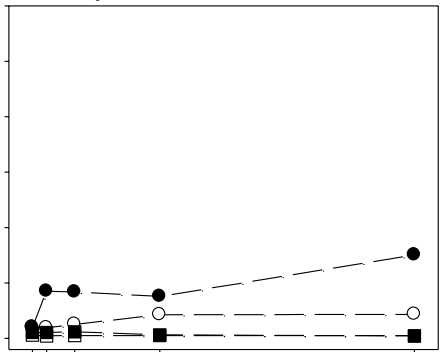

Bo. ornata
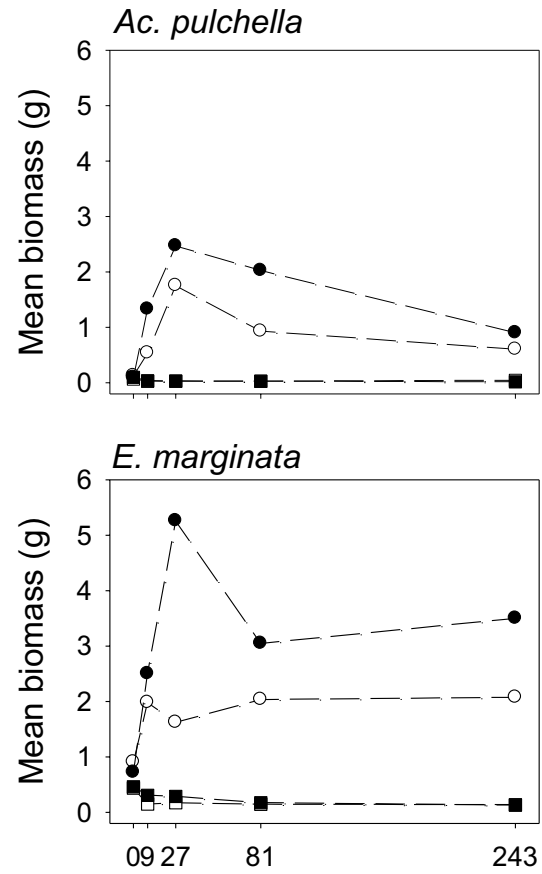

Soil P supply $\left(\mathrm{mg} \mathrm{kg}^{-1}\right)$

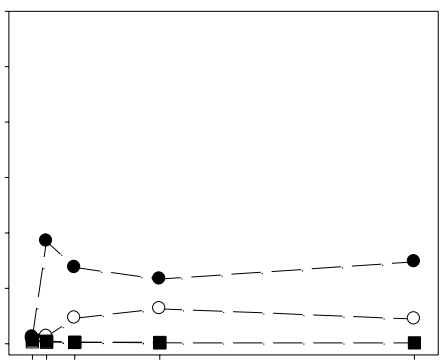

Bo. pulchella

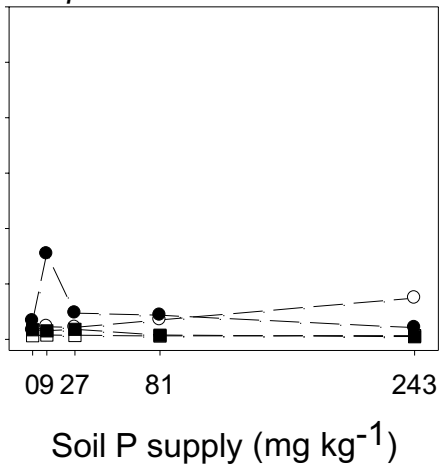

\section{H. prostrata}

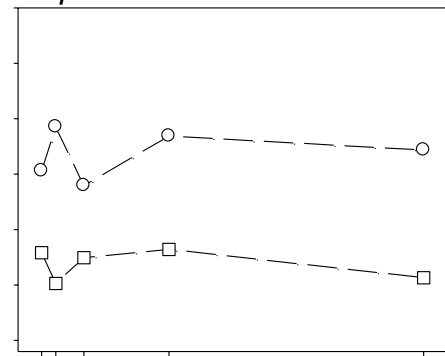

H. undulata

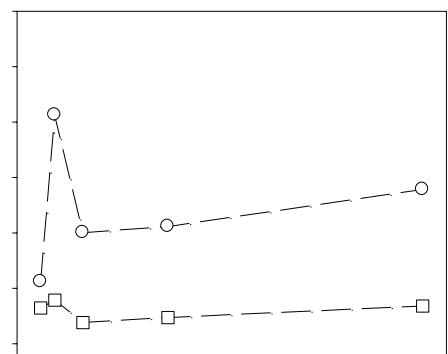

X. gracilis

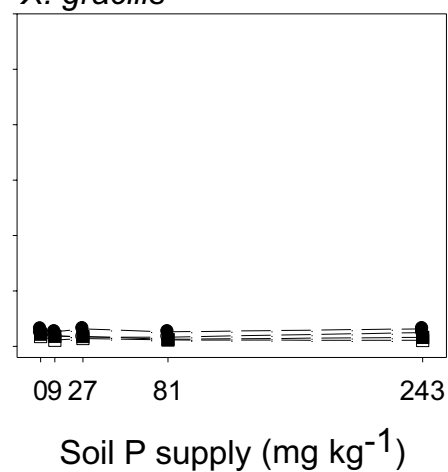

Fig. 2 Raw biomass response of jarrah forest seedlings to increasing soil $\mathrm{P}$ supply, with and without additional nitrogen (30 mg per $\mathrm{kg}$ of soil), and without and without inoculation

in inverse proportions to $\mathrm{KH}_{2} \mathrm{PO}_{4}$ amendments. The $\mathrm{KH}_{2} \mathrm{PO}_{4}$ and the $\mathrm{KCl}$ were mixed into the dry soil. with AM fungi. Values are means per treatment combination $(n=3)$ where $\mathbf{O}=+\mathrm{N}+\mathrm{AM} ; \mathrm{O}=+\mathrm{N}-\mathrm{AM} ; \mathbf{\square}=-\mathrm{N}+\mathrm{AM}$ and $\square=-\mathrm{N}-\mathrm{AM}$. Data for $\mathrm{OP}$ are offset for clarity

Nitrogen, $30 \mathrm{mg} \mathrm{N} \mathrm{kg}{ }^{-1}$ soil, was added as $\mathrm{NH}_{4} \mathrm{NO}_{3}$ dissolved in a modified (minus P) Long Ashton 


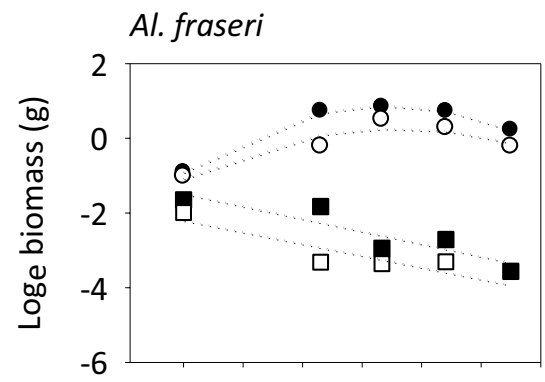

Ac. celastrifolia

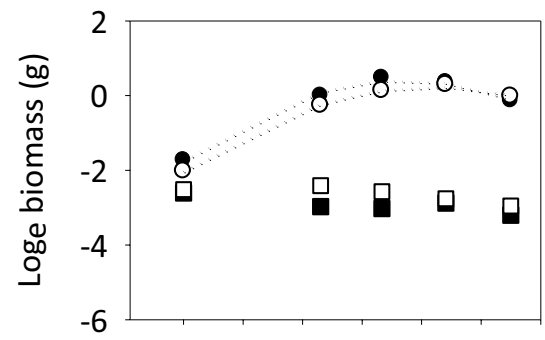

Ac. pulchella

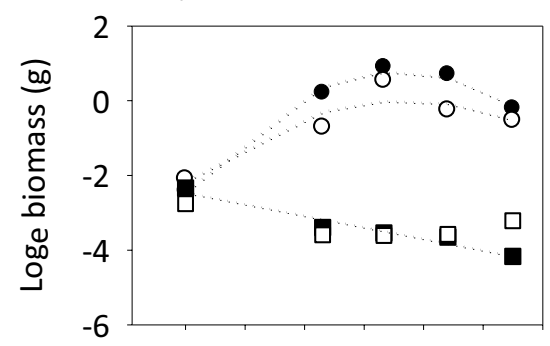

E. marginata

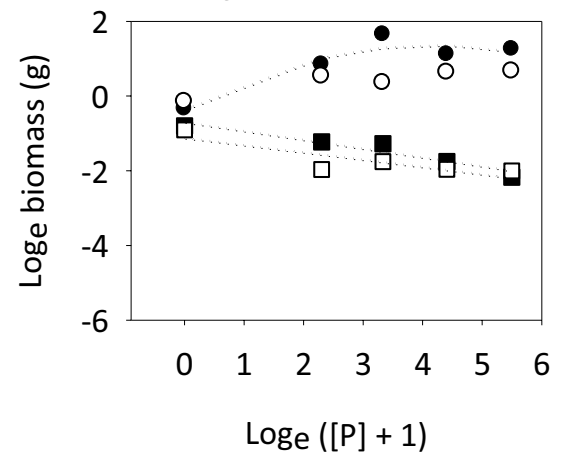

P. calycinus

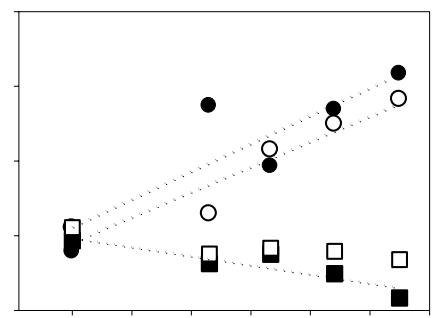

Bo. aquifolium

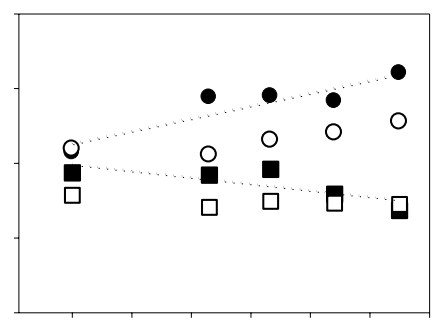

Bo. ornata

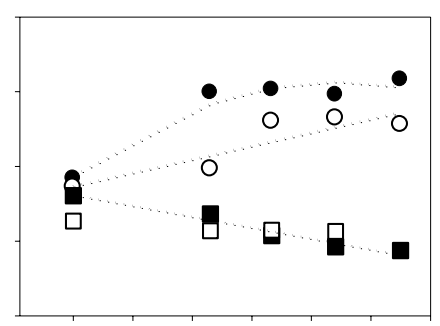

Bo. pulchella

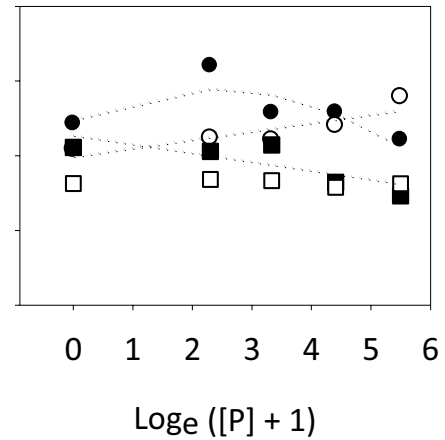

B. grandis

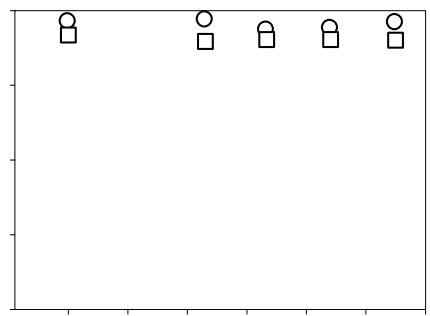

H. prostrata

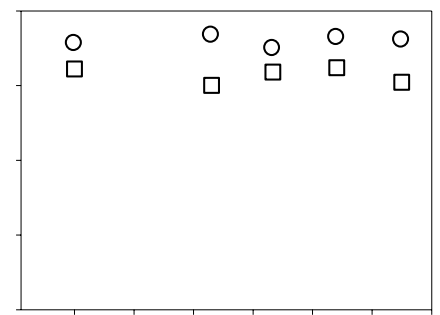

H. undulata

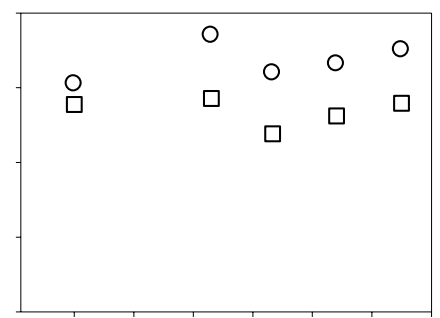

X. gracilis

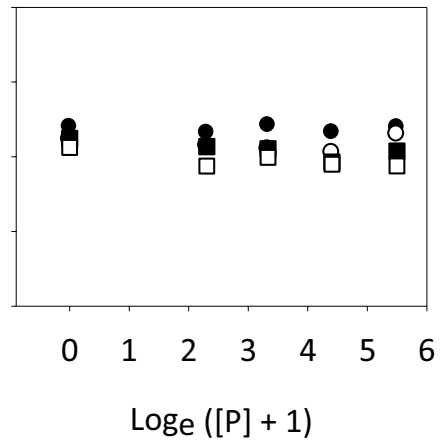

Fig. 3 Modelled biomass response of jarrah forest seedlings to increasing [P]: $0,9,27,81$ and $243 \mathrm{mg}$ added $\mathrm{P}$ per kg dry jarrah forest soil, with and without additional nitrogen $(30 \mathrm{mg}$ per $\mathrm{kg}$ of soil), and without and without inoculation with AM fungi. Values are means per treatment combination $(n=3)$ where: $=+\mathrm{N}+\mathrm{AM} ; \mathrm{O}=+\mathrm{N}-\mathrm{AM} ; \mathbf{\square}=-\mathrm{N}+\mathrm{AM}$ and $\square=-\mathrm{N}-\mathrm{AM}$. Linear and curvilinear relationships were fitted where appropriate $(P<0.02$ for all; Table S2) 

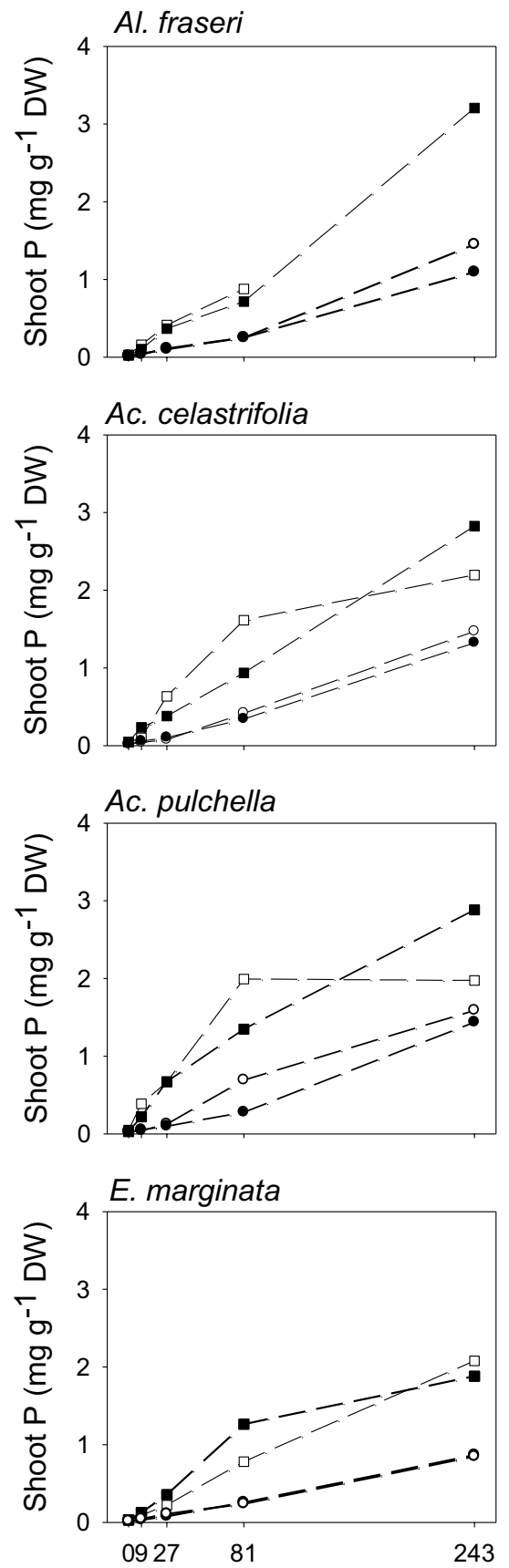

Soil P supply $\left(\mathrm{mg} \mathrm{kg}^{-1}\right)$
P. calycinus

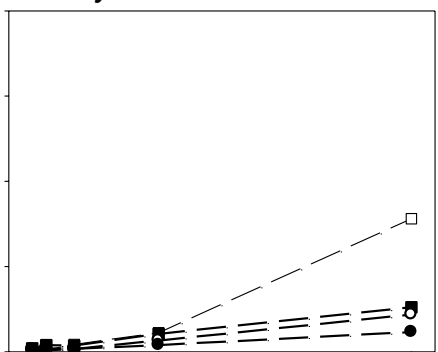

Bo. aquifolium

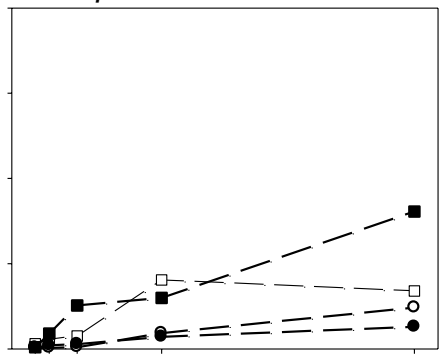

Bo. ornata

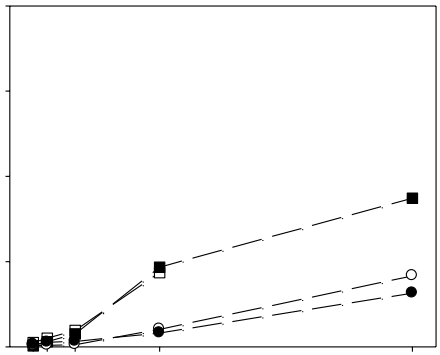

Bo. pulchella

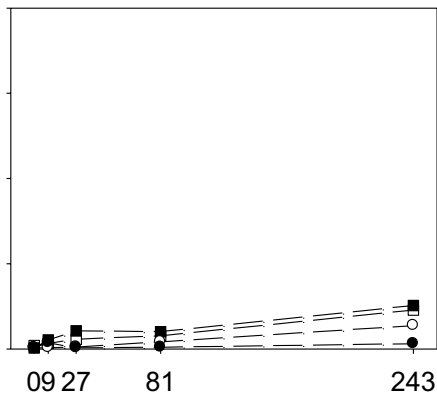

Soil P supply $\left(\mathrm{mg} \mathrm{kg}^{-1}\right)$
B. grandis

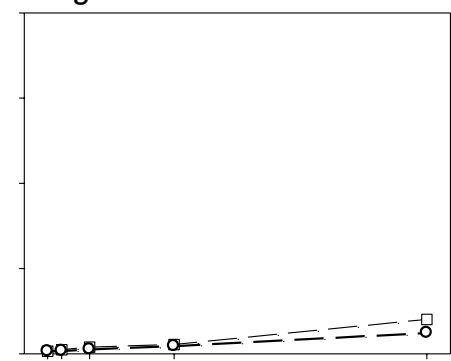

H. prostrata

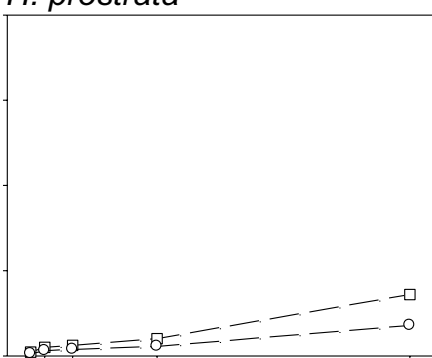

H. undulata

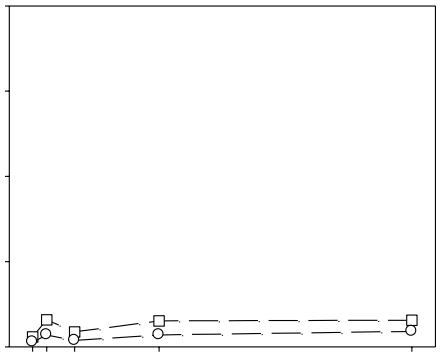

\section{X. gracilis}

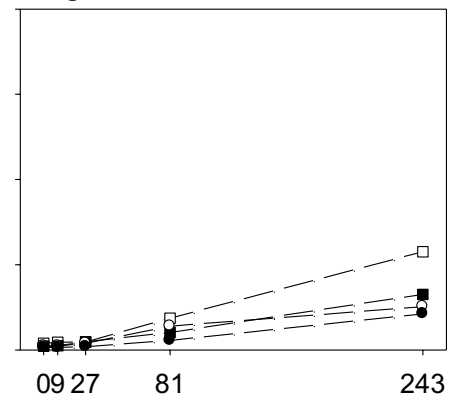

Soil P supply $\left(\mathrm{mg} \mathrm{kg}^{-1}\right)$
Fig. 4 Shoot $\mathrm{P}$ concentrations of jarrah forest seedlings at 5 levels of soil $\mathrm{P}$ supply, with and without additional nitrogen (30 mg per $\mathrm{kg}$ of soil) and without and without inoculation

solution containing micronutrients (Cavagnaro et al. 2001), twice during the experiment. with AM fungi. Values are means per treatment combination $(n=3)$ where $\mathrm{O}=+\mathrm{N}+\mathrm{AM} ; \mathrm{O}=+\mathrm{N}-\mathrm{AM} ; \mathbf{\square}=-\mathrm{N}+\mathrm{AM}$ and $\square=-\mathrm{N}-\mathrm{AM}$

Seedlings were grown from seeds collected within a $20 \mathrm{~km}$ radius of Huntly or Boddington 
Table 2 Mycorrhizal dependency (MD) values for jarrah forest plants grown with and without additional nitrogen $(+\mathrm{N}$ and $-\mathrm{N}$ respectively) at five P-levels. Extreme values are indicated in bold: both beneficial $(\mathrm{MD}>50)$ and parasitic $(\mathrm{MD}<-50)$ associations. $\mathrm{ND}=$ not determined as seedlings in the $-\mathrm{N}+\mathrm{AM}$ treatment died

\begin{tabular}{llllll}
\hline Species (-N) & $0 \mathrm{P}$ & $9 \mathrm{P}$ & $27 \mathrm{P}$ & $81 \mathrm{P}$ & $243 \mathrm{P}$ \\
\hline Allocasuarina fraseriana & 22.0 & $\mathbf{7 7 . 4}$ & 34.4 & 44.9 & $\mathrm{ND}$ \\
Acacia celastrifolia & -7 & -42.2 & -33.7 & -16.2 & -13.7 \\
Acacia pulchella & 33.5 & 20.5 & 6.5 & -5.8 & $\mathbf{- 1 5 9 . 3}$ \\
Eucalyptus marginata & 4.6 & $\mathbf{5 0 . 7}$ & 39.5 & 17.7 & -5.5 \\
Phyllanthus calycinus & -34.0 & -17.9 & 42.3 & $\mathbf{- 9 8 . 5}$ & $\mathbf{- 1 9 8 . 6}$ \\
Bossiaea aquifolium & 43.9 & $\mathbf{5 9 . 1}$ & $\mathbf{5 7 . 9}$ & 20.0 & -7.6 \\
Bossiaea ornata & 48.6 & 39.2 & -1.2 & $\mathbf{- 5 0}$ & $\mathrm{ND}$ \\
Bossiaea pulchella & $\mathbf{6 1 . 3}$ & 48.9 & $\mathbf{6 1 . 7}$ & 20.2 & -36.5 \\
Xanthorrhoea gracilis & 20.0 & 39.2 & 20.1 & 9.5 & 33.1 \\
Means \pm SE & $21.4 \pm 10.0$ & $30.5 \pm 12.7$ & $25.3 \pm 10.2$ & $-6.5 \pm 14.6$ & $-55.4 \pm 33.0$ \\
Species (+N) & $0 \mathrm{P}$ & $9 \mathrm{P}$ & $27 \mathrm{P}$ & $81 \mathrm{P}$ & $243 \mathrm{P}$ \\
Allocasuarina fraseriana & 14.4 & $\mathbf{6 1 . 7}$ & 28.9 & 32.5 & 17.3 \\
Acacia celastrifolia & 24.6 & 25.7 & 28.7 & 10.6 & -9.0 \\
Acacia pulchella & -32.6 & $\mathbf{5 9 . 7}$ & 29.1 & $\mathbf{5 4 . 2}$ & 32.9 \\
Eucalyptus marginata & -25.8 & 20.9 & $\mathbf{6 9 . 2}$ & 33.2 & 40.7 \\
Phyllanthus calycinus & $\mathbf{- 7 3 . 6}$ & $\mathbf{9 6 . 6}$ & -42.1 & 22.9 & $\mathbf{5 2 . 8}$ \\
Bossiaea aquifolium & -2.3 & $\mathbf{7 7 . 8}$ & $\mathbf{7 0 . 0}$ & 44.0 & $\mathbf{7 1 . 1}$ \\
Bossiaea ornata & 30.7 & $\mathbf{9 3 . 1}$ & $\mathbf{6 6 . 7}$ & 45.9 & $\mathbf{6 9 . 8}$ \\
Bossiaea pulchella & $\mathbf{5 1 . 1}$ & $\mathbf{8 5 . 2}$ & $\mathbf{5 5 . 0}$ & 19.0 & $\mathbf{- 2 5 9 . 4}$ \\
Xanthorrhoea gracilis & 23.2 & 26.6 & 47.0 & 36.2 & 21.3 \\
Means \pm SE & $1.1 \pm 12.9$ & $60.8 \pm 10.0$ & $39.2 \pm 11.7$ & $33.2 \pm 4.6$ & $1.2 \pm 34.0$ \\
\hline
\end{tabular}

(3248'13.61"S 116²8'25.04"E), Western Australia. Seeds were either immersed in boiling water for $30 \mathrm{~s}$, treated with aerosol smoke or soaked in smoke-water to stimulate germination and surface sterilised by immersing in $0.5 \%(\mathrm{v} / \mathrm{v})$ sodium hypochlorite solution for $10 \mathrm{~min}$. Seeds were placed on moistened filter paper in Petri dishes, and these were placed in a dark $15{ }^{\circ} \mathrm{C}$ constant-temperature room. The germinants were planted into the pots between 31 July and 15 August 2007. Soils were watered to field capacity (18.7\% DI water by weight) every four days. Alkathene polyethylene beads (Qenos Pty Ltd, Altona, Victoria, Australia) were added to the soil surface within each pot to minimise evaporation and to help prevent mycorrhizal contamination of non-mycorrhizal treatments. Germinants that did not emerge, and dead seedlings, were replaced within six weeks after 31 July 2007.

\section{Response variables}

We harvested species in size order from largest to smallest; we started harvesting Acacia celastrifolia on $21^{\text {st }}$ November 2007 and finishing harvesting
Xanthorrhoea gracilis on $6^{\text {th }}$ February 2008. The temperature in the glasshouse ranged from $8-39{ }^{\circ} \mathrm{C}$ during the growth period and seedlings were aged between 14 and 27 weeks at harvest. Plant shoots (i.e. aboveground material) were oven-dried at $70{ }^{\circ} \mathrm{C}$ and weighed. Shoot $\mathrm{P}$ was determined by digesting ground plant material in a mixture of $70 \%(\mathrm{v} / \mathrm{v})$ nitric acid and concentrated perchloric acid and measured by ICP-OES (Zarcinas 1984). We determined seed P using the same methodology, on seeds leftover from our original collection, and seed $\mathrm{N}$ was determined using a Vario Macro combustion analyser (Elemental Analysis GmbH, Hanau, Germany).

The roots were washed, dried with paper towel, and weighed; the cluster roots and the nodules were counted. Then, $0.1 \mathrm{~g}$ (fresh weight) of the fine roots were removed and stored in $50 \%(\mathrm{v} / \mathrm{v})$ ethanol pending assessment of mycorrhizal colonisation. The remaining roots were oven-dried at $70{ }^{\circ} \mathrm{C}$ and weighed; the root biomass includes an estimate of the dry weight of the fine-roots sampled for mycorrhizal colonisation. The biomass of the cluster roots was estimated by subtracting the loss-on-ignition (at $650{ }^{\circ} \mathrm{C}$ for $16 \mathrm{~h}$ ) of organic matter from soil 
only ( 2\%; Table S1) with that from cluster roots with soil attached. Raw data were visualised in biomass response plots to allow comparison to other $\mathrm{P}$ response studies. Subsequently, we modelled $\mathrm{P}$ response using linear mixed models and linear and curvilinear relationships were fitted where appropriate (see below).

The fine-root samples were cleared in $10 \%(\mathrm{w} / \mathrm{v})$ $\mathrm{KOH}$ at room temperature for 5 days, and then stained in a 5\% (v/v) black ink vinegar solution for $1 \mathrm{~h}$ before being transferred to a solution of lactoglycerol (Walker 2005). The dark roots of A. fraseriana, E. marginata and $X$. gracilis were bleached in a $0.5 \%$ $(\mathrm{v} / \mathrm{v})$ sodium hypochlorite solution prior to staining. The line intercept method at $40 \times$ magnification was used to assess the percentage root length colonised by Rhizophagus irregularis (Giovanetti and Mosse 1980).

Mycorrhizal growth dependency is defined as the ratio of the biomass of plants inoculated with AM to that of uninoculated plants; a mycorrhizal dependency $>0$ means that plant growth was enhanced by AM inoculation (Gerdemann 1975). The mycorrhizal growth dependency of each plant species was determined for each combination of $\mathrm{P}$ and $\mathrm{N}$ treatments using the equation from Plenchette et al. (1983):

MD $\frac{\text { Biomass mycorrhizal plant }- \text { biomass non }- \text { mycorrhizal plant }}{\text { Biomass mycorrhizal plant }} \times 100 \%$

We used the average biomass values of mycorrhizal and non-mycorrhizal seedlings for each of the treatment combinations.

\section{Statistical analyses}

The changes in seedling biomass in response to the $\mathrm{P}$ gradient were analysed using linear mixed models. These models are used to analyse data with more than one variance component, and which include both fixed and random effects (Galwey 2006). They are also appropriate for the analysis of unbalanced designs such as this one (i.e. three non-mycorrhizal species were not inoculated with AM). We fitted up to four regression lines for each species, corresponding to the factorial combinations of $\mathrm{N}$ and AM treatments. The $y$ (biomass of shoot+root+clusters) and $x$ variables (P-levels) were natural-log transformed prior to analysis. The biomass response to $\mathrm{P}$ (hereafter P-response) was modelled by fitting linear and quadratic functions to the transformed data sets. N-treatment, species nested within nutrientacquisition strategy (mycorrhizas or cluster roots), and AM nested within mycorrhizal species were included as fixed effects; the replicates, second and higher order interactions were included as random effects. The models were fitted using the residual maximum likelihood (REML) procedure in GenStat (Payne et al. 2008). The Wald statistic was estimated to test for the significance of the terms and their interactions (Elston 1998). The highest order interactions were dropped from the final model.

We used a two-factor ANOVA to compare mycorrhizal growth dependency (MD) among $\mathrm{N}$ and $\mathrm{P}$ treatment combinations followed by a Fisher's Least Significant Difference test to determine the pairwise differences between the P-treatment means. The MD values of plants grown at $243 \mathrm{mg} \mathrm{P} \mathrm{kg}^{-1}$ soil were highly variable, so we excluded these from the analyses so that the remaining dataset conformed to the assumption of homoscedasticity. Data were reflected and $\log _{\mathrm{e}}$ transformed prior to analysis. We also used a two-factor ANOVA to compare shoot $\mathrm{P}$ concentrations; the factors were $\mathrm{N}$-treatment and nutrient acquisition strategy. We excluded non-mycorrhizal seedlings from these analyses, so the sample sizes were equal. These and the preceding ANOVAs were conducted using GenStat Version 11.1 (Payne et al. 2008).

\section{Results}

Mycorrhizal colonisation and cluster root formation

For AM-inoculated seedlings, the percentage length of fine roots colonised by Rhizophagus irregularis varied among species: Xanthorrhoea gracilis 0-1\%, Eucalyptus marginata 0-6\%, Acacia celastrifolia 0-37\%, Acacia pulchella 0-47\%, Allocasuarina fraseri 0-48\%, Bossiaea ornata 0-51\%, Bossiaea pulchella 0-51\%, Bossiaea aquifolium 0-68\%, Phyllanthus calycinus 0-90\%. Percentage AM colonisation varied widely within and among $\mathrm{P} / \mathrm{N}$ treatment combinations for all species except $X$. gracilis (i.e., AM colonisation was consistently low), and except for percentage AM colonisation at the highest $\mathrm{P}$ supply which was consistently low for all species except $P$. calycinus (Fig. 1).

There were no statistically significant effects of $\mathrm{N}$ addition and increasing $\mathrm{P}$ on the biomass of cluster roots, expressed as a proportion of the total root 
Table 3 Results of 2-factor ANOVA on Mycorrhizal growth dependency (MD; Table 2). Pairwise differences between P-treatment means determined by Fisher's Protected Least Sig- nificant Difference Test $(P=0.05)$ are indicated by different subscript letters: $17.62^{\mathrm{a}}(0 \mathrm{P}), 63.24^{\mathrm{b}}(9 \mathrm{P}), 39.12^{\mathrm{a}}(27 \mathrm{P}), 19.44$ ${ }^{a}(81 \mathrm{P})$. These means are back transformed

\begin{tabular}{llrr}
\hline Source of variation & Mean square value $(\mathrm{df})$ & $F$-statistic & $P$-value \\
\hline N-treatment & $0.486(1,64)$ & 5.93 & 0.02 \\
P-treatment & $0.525(3,64)$ & 6.41 & $<0.001$ \\
N-treatment $\times$ P-treatment & $0.239(3,64)$ & 2.92 & 0.04 \\
Residual & $0.082(64)$ & & \\
\hline
\end{tabular}

biomass, for the three cluster-root-forming species (data not shown).

\section{Plant growth}

Plant growth was strongly affected by $\mathrm{N}$ addition in all but one species, $X$. gracilis (Fig. 2). Eight of the nine mycorrhizal species showed positive (linear or curvilinear) biomass responses to increasing $\mathrm{P}$ addition for at least one of the N/AM treatment combinations (Fig. 3). For these species, the effect of $\mathrm{P}$ was constrained by the availability of $\mathrm{N}$, and the biomass response to $\mathrm{N}$ addition was greater than the biomass response to inoculation with the AM fungus (Fig. 2). The remaining four species-the three proteaceous species and $X$. gracilis-did not show any biomass response to increasing $\mathrm{P}$ with or without additional $\mathrm{N}$ (Fig. 4). For the mycorrhizal species (incl. X. gracilis), seedlings grown in soil containing AM inoculum and additional $\mathrm{N}$ attained the highest biomass compared with the other N/AM treatment combinations. Without additional $\mathrm{N}$, the biomass of mycorrhizal seedlings declined with increasing soil $\mathrm{P}$ for six of the nine mycorrhizal species (Fig. 3 and Table 2 and next section). Most of the interaction terms in the model were statistically significant (Table S2).
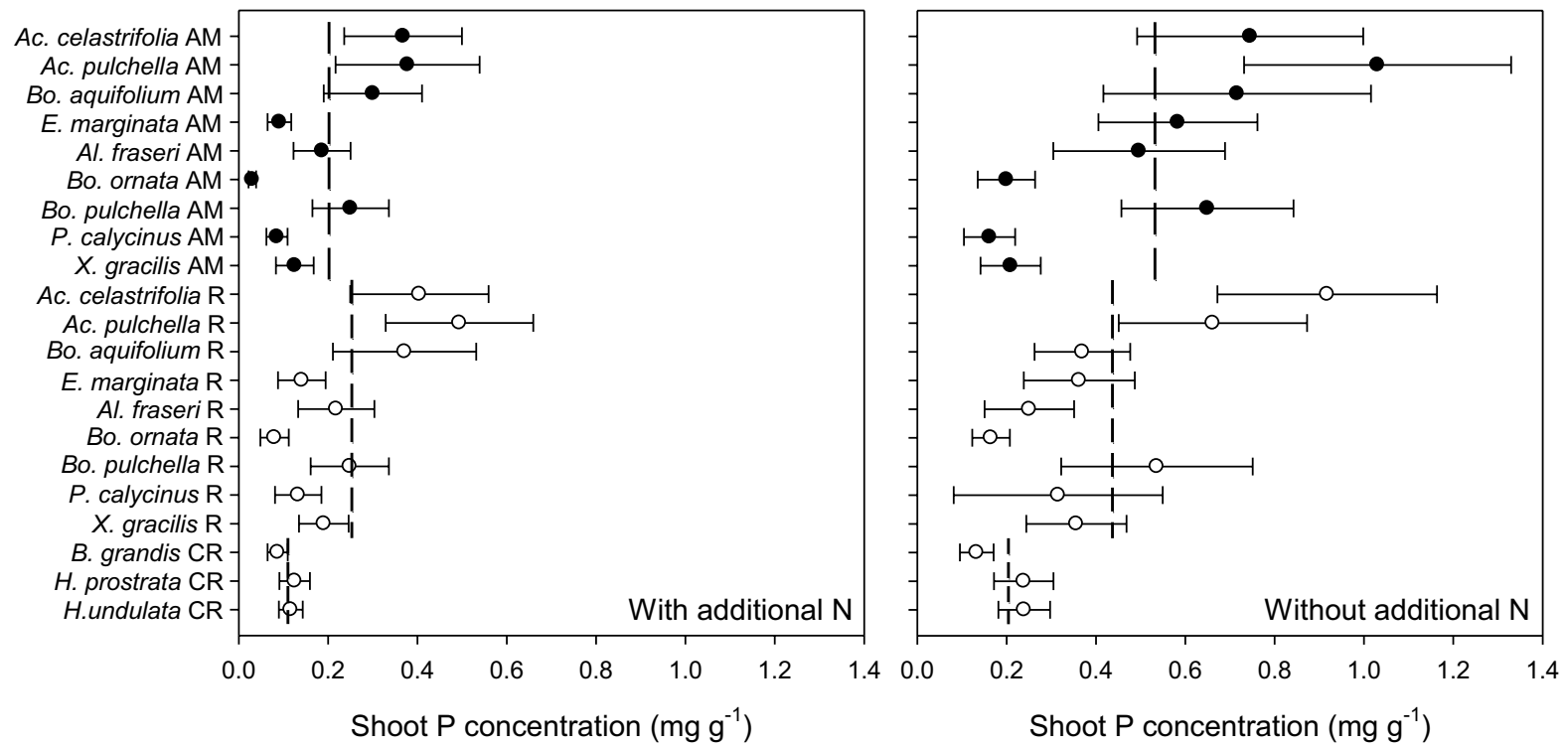

Fig. 5 Shoot $\mathrm{P}$ concentration for 12 jarrah forest species, with and without additional nitrogen ( $30 \mathrm{mg}$ per $\mathrm{kg}$ of soil), and without and without inoculation with $\mathrm{AM}$ fungi. $\mathrm{AM}=$ mycorrhizal seedlings (filled symbols); $\mathrm{R}=$ roots alone and $\mathrm{CR}=$ cluster roots (open symbols). Values are means $\pm \mathrm{SE}$ of five external $\mathrm{P}$ concentrations, except for Al. fraseri $R$ and
Bo. ornata $R$ at $243 \mathrm{P}$ as these seedlings died. Dashed lines are means for AM, R and CR seedlings, respectively. Differences between nutrient acquisition strategy and $\mathrm{N}$-treatment, excluding non-inoculated seedlings (R), were statistically significant (Table 4) 
Table 4 Results of 2-factor ANOVA (Type II Sums of Squares) on Shoot P concentrations (Fig. 4). Nutrient acquisition strategy (NAS) has two levels: cluster roots ( $n=3$ species) and mycorrhizal ( $n=9$ species); non-inoculated seedlings were excluded from these analyses

\begin{tabular}{|c|c|c|c|}
\hline Source of variation & $\begin{array}{l}\text { Mean square value } \\
\text { (df) }\end{array}$ & $F$-statistic & $P$-value \\
\hline N-treatment & $0.575(1,20)$ & 11.363 & 0.003 \\
\hline $\begin{array}{l}\text { Nutrient acquisi- } \\
\text { tion strategy } \\
\text { (NAS) }\end{array}$ & $0.25(1,20)$ & 4.958 & 0.038 \\
\hline $\mathrm{N}$-treatment $\times \mathrm{NAS}$ & $0.092(1,20)$ & 1.814 & 0.193 \\
\hline Residual & 0.51 & & \\
\hline
\end{tabular}

The biomass of the seedlings reflected their seed masses and seed nutrient reserves; in particular, $B$. grandis attained greater biomass than seedlings of the other species (Fig. 2 and Table 1). The two species with the smallest seeds had the highest mean root: shoot ratios $( \pm \mathrm{SE}): 3.09 \pm 0.85$ and $1.86 \pm 0.19$ for non-mycorrhizal $P$. calycinus and Bo. ornata respectively, but then, other small-seeded species such as Bo. aquifolium, had comparatively low mean root: shoot ratios $(0.34 \pm 0.02$ for non-mycorrhizal seedlings).

Mycorrhizal growth dependency

Mycorrhizal growth dependency (MD) values were generally higher when seedlings had access to $\mathrm{N}$, although the reverse was true for seedlings grown at $\mathrm{OP}$, and seedlings grown at $9 \mathrm{mg} \mathrm{P} \mathrm{kg}^{-1}$ benefitted from AM more than seedlings grown at the other $\mathrm{P}$ concentrations (Tables 2 and 3). The mean difference in MD values $( \pm 95 \%$ CIs $)$ is presented in Table 2 . Growth benefits at $9 \mathrm{mg} \mathrm{P} \mathrm{kg}{ }^{-1}$ were particularly evident for small-seeded species (Tables 2 and 3). In most cases, AM were parasitic on seedlings grown at $243 \mathrm{mg} \mathrm{P} \mathrm{kg}^{-1}$ without additional N (Table 2).

\section{Shoot $\mathrm{P}$ concentration}

For the 12 study species, shoot $\mathrm{P}$ concentrations increased with increasing external $P$ concentrations reaching a maximum of ca. $1-3 \mathrm{mg} \mathrm{P} \mathrm{g}^{-1} \mathrm{DW}$ of shoot tissue (Fig. 4). Across the five external P concentrations, shoot $\mathrm{P}$ concentration was significantly higher both for the AM species compared with the cluster root species (Fig. 5 and Table 4) and when seedlings were grown without additional N (Fig. 5 and Table 4).

\section{Discussion}

Responses to P depend on nutrient acquisition strategy

Seedling responses of the 12 jarrah forest species to $\mathrm{P}$ could be separated into three broad groups (Fig. 6). Group 1 included the mycorrhizal species Allocasuarina fraseri, Acacia celastrifolia, Ac. pulchella, Bossiaea aquifolium, Bo. ornata, Bo. pulchella, Eucalyptus marginata and Phyllanthus calycinus. These species showed a positive growth response to increasing soil $\mathrm{P}$ when $\mathrm{N}$ was available and a generally negative growth response to $\mathrm{P}$ in the absence of additional $\mathrm{N}$ (Fig. 6). The second seedling response evident among the 12 jarrah forest species was represented by Xanthorrhoea gracilis. It did not respond like the other mycorrhizal species. This species fits the classical description of plants from nutrient-poor soils: low growth rate and no nutritional response to increasing $\mathrm{P}$ supply (Chapin 1980). Its low growth rate relative to the other species we tested, constrained its ability to respond to increased soil $\mathrm{P}$ and $\mathrm{N}$, although it benefited from its association with Rhizophagus irregularis, irrespective of P supply (Fig. 6).

The third group was defined by the proteaceous species Banksia grandis, Hakea prostrata and $H$. undulata. These species exhibited no growth response to increasing soil P (Fig. 6). Instead, seedling growth probably relied on seed nutrient reserves (Barrow 1977; Pate et al. 1990; Stock et al. 1990) which may also explain the limited response of shoot $\mathrm{P}$ concentration to increasing $\mathrm{P}$. This seedling strategy is also evident among proteaceous fynbos shrubs growing on similarly nutrient-poor soils (Allsopp and Stock 1995). Using published data for root [P] (Pate et al. 1990), we estimated that the seed $\mathrm{P}$ reserves of $H$. undulata were almost depleted when the seedlings were harvested, whereas the larger seed $P$ reserves of $B$. grandis were probably only half consumed at harvest. Soil $\mathrm{P}$ will become more important as the seed nutrient reserves are depleted (Mitchell and Allsopp 


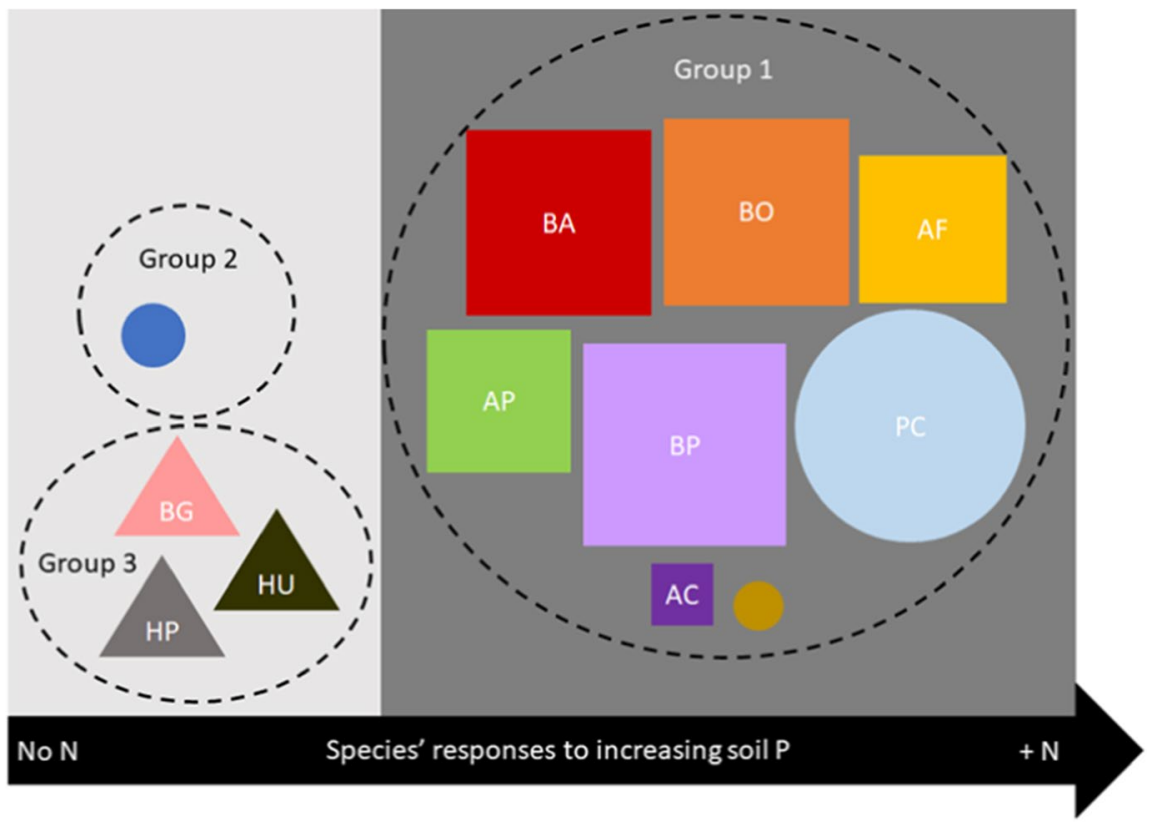

Fig. 6 Schematic representation of the three distinct nutritional responses of species' suggested by our data. Mycorrhizal species are represented by circles and $\mathrm{N}$-fixing mycorrhizal species are represented by squares; with the sizes of each symbol relative to species' mycorrhizal dependency at $9 \mathrm{~kg}$ phosphorus (P) per $\mathrm{kg}$ of soil and with additional nitrogen (N). Cluster-root forming species are represented by triangles. Group 1: Positive growth response to $\mathrm{P}$ when $\mathrm{N}$ available;

1984) and the seedlings become reliant on cluster roots for nutrient acquisition. For these species, an increasing $\mathrm{P}$ supply did not suppress the formation of cluster roots as might be expected (e.g. Lamont 1972b; Shane and Lambers 2005, 2006). This result is potentially explained by the strongly P-fixing properties of jarrah forest soil (Bolan et al. 1983; Handreck 1997). The phosphorus retention index of jarrah forest soils can be as high as 90 (Tibbett et al. 2020).

P-sensitivity to high external $\mathrm{P}$ concentrations in the absence of mycorrhiza

P-toxicity symptoms were not observed for any of the study species even at the highest amendment rate of $243 \mathrm{mg} \mathrm{P} \mathrm{kg}^{-1}$. The shoot $\mathrm{P}$ concentrations we recorded for the study species were consistently below those at which we would expect visible symptoms of P-toxicity to develop, i.e., $<10 \mathrm{mg} \mathrm{g}^{-1} \mathrm{DM}$ (Lambers et al. 2002; Shane et al. 2004b). While there were no visible symptoms of P-toxicity for
Group 2 No response to $\mathrm{P}$ with or without N; Group 3: No response to $\mathrm{P}$ with or without $\mathrm{N}$. $\mathrm{BA}=$ Bossiaea aquifolium, $\mathrm{BO}=$ Bo. ornata, $\mathrm{AF}=$ Allocasuarina fraseriana, $\mathrm{AP}=$ Acacia pulchella, $\mathrm{BP}=$ Bo. pulchella, $\mathrm{PC}=$ Phyllanthus calycinus, $\mathrm{AC}=$ Ac. celastrifolia, Eucalyptus marginata is the unlabelled amber coloured circle in Group 1. Xanthorrhoea gracilis is unlabelled blue circle in Group 2. $\mathrm{BG}=$ Banksia grandis, $\mathrm{HU}=$ Hakea undulat $a$ and $\mathrm{HP}=H$. prostrata

the study species, we observed a decline in growth increasing $\mathrm{P}$ supply for at least half of the species, most commonly in the absence of exogenous $\mathrm{N}$ supply. For some species e.g. Allocasuarina fraserii, total biomass was reduced at $243 \mathrm{mg} \mathrm{P} \mathrm{kg}^{-1}$ compared with $81 \mathrm{mg} \mathrm{P} \mathrm{kg}^{-1}$, and this occurred irrespective of AM inoculation.

These responses may be partly due to the high P-fixing properties of jarrah forest soil, causing the amended $\mathrm{P}$ to become partially or wholly unavailable to plants. While highly weathered and P-deplete, these soils contain large amounts of reactive iron and aluminium, which adsorbs available $\mathrm{P}$, and this capacity can be assessed by the $\mathrm{P}$ retention index (Allen and Jeffery 1990). A P retention index of 90 for jarrah forest soils (Tibbett et al. 2020) is high by global standards and even compared to other Western Australian soils (Bolland and Russell 2010; Bolland and Windsor 2007). This high $\mathrm{P}$ retention index may explain the modest responses to amended $\mathrm{P}$, which would only be partially available to plants. The 
precise quotient is impossible to estimate with any accuracy.

The reduction in growth at high $\mathrm{P}$ amendment has some similarities to the work of Pang et al. (2010), who showed growth reductions for several species of perennial legumes, including native Australian species. These authors used higher $\mathrm{P}$ amendments (up to $384 \mathrm{mg} \mathrm{kg}^{-1}$ ) and grew the plants in a washed river sand, in which nearly all amended $\mathrm{P}$ would be readily available. Some species show growth declines from as low as $24 \mathrm{mg} \mathrm{kg}^{-1}$ for Australian natives such as Kennedia spp. and perhaps we would have observed physiological toxicities and growth reduction at high $\mathrm{P}$ amendment if the plants were grown in sand culture. Importantly however, we show growth reductions are possible even when seedlings were grown in native high P-fixing jarrah forest soils, which is more relevant than sand for informing fertiliser application for jarrah forest restoration.

Mycorrhizas limit growth suppression at high external P concentrations

While AM fungal inoculation has been shown to reduce the effect of elevated $\mathrm{P}$ on visible symptoms of toxicity in Eucalyptus marginata (Kariman et al. 2014; Tibbett et al. 2021), our study showed no evidence of AM inoculation moderating its decline in biomass at 81 and $243 \mathrm{mg} \mathrm{P} \mathrm{kg}^{-1}$. Across species, the shoot $\mathrm{P}$ concentration at which biomass declined was approx. $3 \mathrm{mg} \mathrm{g}^{-1} \mathrm{DM}$, which is similar to the concentrations reported by Williams et al. (2019) at which negative effects on growth were observed for woody species from the Great Western Woodlands of Western Australia. However, shoot P concentrations closer to $10 \mathrm{mg} \mathrm{g}^{-1} \mathrm{DM}$ were required to trigger growth reductions in perennial legumes.

There were three consistent effects of increasing P supply on mycorrhizal growth dependency among the jarrah forest species: (i) a decline in percentage colonisation of fine roots by the AM fungus at high $\mathrm{P}$ supply (243 $\mathrm{mg} \mathrm{P} \mathrm{kg}^{-1}$ soil); (ii) the AM fungus was more beneficial to plant growth at low P $(9 \mathrm{mg}$ $\mathrm{P} \mathrm{kg}^{-1}$ soil) than at the other P-levels $(0,27,81$ and $243 \mathrm{mg} \mathrm{P} \mathrm{kg}^{-1}$ soil) and; (iii) seedling dry mass was less at high $\mathrm{P}$ supply compared with lower external $\mathrm{P}$ concentrations, which we interpret evidence for the AM fungus being parasitic on seedlings (sensu Johnson et al. 1997). Although the levels of mycorrhizal colonisation that we observed were low, they were consistent with those observed in other studies of jarrah forest species (Kariman et al. 2014; Nazeri et al. 2014). The decline in colonisation with increasing $\mathrm{P}$ confirms a common observation for both natural and agricultural systems (Smith and Read 2008 but see Jasper et al. 1989). The transition from mutualism to parasitism with increasing $\mathrm{P}$ supply supports other studies that have reported the importance of soil nutrient availability for determining the nature of the relationship between plants and mycorrhizal fungi (Johnson et al. 2010; Johnson 2010; Neuenkamp et al. 2019). The trade balance model predicts mutualism in soils with low $\mathrm{P}$ and $\mathrm{N}$ and conversely, parasitism in soils with high soil $\mathrm{P}$ and $\mathrm{N}$ (Johnson 2010). We confirmed this prediction for one fungus, a species considered 'ruderal' in Grime's CSR framework (Chagnon et al. 2013); the next step would be to determine the nature of the symbiosis for other jarrah forest fungi.

$\mathrm{N}$ addition will effect species specific $\mathrm{P}$ responses

The treatment that gave the most consistent response across all species was $\mathrm{N}$ addition to the $\mathrm{P}$ treatments. This treatment caused a large variation in the amended $\mathrm{N}: \mathrm{P}$ ratio, eightfold difference compared with pots without applied $\mathrm{N}$, with the difference being maintained throughout the experiment because pots were watered to weight (i.e. nutrients did not leach). Positive seedling growth responses to $\mathrm{P}$ were generally observed with $\mathrm{N}$ addition and did not occur without $\mathrm{N}$ addition. While shoot $\mathrm{P}$ concentrations were consistently higher without $\mathrm{N}$ addition, they were still lower than the range at which reductions in growth have been observed in tree seedlings (e.g. Williams et al. 2019). This suggests two important aspects of nutrition at play. Firstly, in unamended soils (-N, and $-\mathrm{P}$ ) both $\mathrm{N}$ and $\mathrm{P}$ may be growth limiting, and the addition of $\mathrm{N}$ ensures only $\mathrm{P}$ is growth-limiting and causes biomass to increase broadly in line with increasing $\mathrm{P}$ application rate in Group 1 (mycorrhizal) species, with some growth decline at the highest amendment rate. Secondly, in the absence of $\mathrm{N}$ addition, Group 1 (mycorrhizal) species showed a decline in response broadly in line with increasing $\mathrm{P}$ rate and concomitant with tissue $\mathrm{P}$ concentration. We postulate that this is due to a poor capacity to regulate $\mathrm{P}$ uptake, due to the loss of high affinity transporters 
(Huang et al. 2011), in these Gondwanan trees without the ability to dilute acquired $\mathrm{P}$ in greater biomass allowed by $\mathrm{N}$ addition. This finding also demonstrates the importance of N:P ratio in forest ecosystem development (e.g. Amazonas et al. 2011), which is often overlooked in the assessment of ecosystem nutrition for restoration (Tibbett et al. 2019).

Further studies are required to determine the mechanism behind the reduction in growth when $\mathrm{P}$, but not $\mathrm{N}$, were added. Nonetheless, this growth reduction has the potential to be ecologically significant in a field setting. Current practice in large areas of post-mining restoration in the jarrah forest is to apply single superphosphate without additional N (e.g. Worsley Alumina; George et al. 2006). Thus, while for each individual species in Fig. 2, the area encompassed by the suite of lines likely represents the potential range of growth responses to applied $\mathrm{N}$ and $\mathrm{P}$, the actual seedling growth response in the field may be closer to the $\mathrm{P}$ only treatments, i.e. a reduction in growth across a range of species, at least for the species that do not fix nitrogen.

Our findings are consistent with field-based studies of restored jarrah forest where mycorrhizal species generally have access to arbuscular mycorrhizal fungi and $\mathrm{N}$-fixing species have access to rhizobia and Frankia (Jasper 2007). For example, Tibbett et al. (2020) found that in one-year old restored sites, species richness was higher when $\mathrm{N}$ was included in the applied fertiliser mix as opposed to applying just single superphosphate. Indeed, our current data suggests this observation may result from the reduced growth of some species when just $\mathrm{P}$ is applied. Daws et al. (2013) reported that after 2.5 years the proteaceous species $B$. grandis exhibited no growth response to a single, initial application of up to $40 \mathrm{~kg} \mathrm{P} \mathrm{ha}^{-1}$, while the AM species jarrah doubled in size as $\mathrm{P}$ increased from 0 to $40 \mathrm{~kg} \mathrm{ha}^{-1} \mathrm{P}$, and the two $\mathrm{N}$-fixing AM species Acacia drummondii and A. lateriticola exhibited an almost six-fold increase in plant size as applied $\mathrm{P}$ increased from 0 to $40 \mathrm{~kg} \mathrm{P} \mathrm{ha}^{-1}$. Indeed, P-addition can result in legumes dominating the understorey in restored sites because of their ability to fix $\mathrm{N}$ and exploit P (e.g. Grant 2006). Tibbett et al. (2020) reported that restored mine sites which received a single application of superphosphate were dominated by the fast-growing legume Ac. celastrifolia in just one year, with negative effects on the abundance of slower growing resprouter species. In contrast, in the zero $\mathrm{P}$ control, Ac. celastrifolia growth was minimal and the abundance of resprouter species. Indeed, from the perspective of plant community composition, a single initial application of $\mathrm{P}$ can reduce the species richness and density of long-lived resprouter species, including species such as $X$. gracilis and the cluster root forming Proteaceae, for 15 or more years after the initiation of restoration (Daws et al. 2019a, b).

\section{Conclusions}

The conundrum for practitioners working to restore native plant communities that have evolved in ecosystems with naturally nutrient-poor soils, such as those under jarrah forest, is to apply P-fertiliser in amounts that will facilitate rapid plant establishment without favouring some species more than others. Our results imply that higher rates of P-fertiliser $(27-243 \mathrm{~kg}$ $\mathrm{P} \mathrm{ha}^{-1}$ ) are likely to promote the dominance of P-responsive jarrah forest species, especially those that fix N. Our data also suggest that AM fungi will benefit seedling establishment in soils where $\mathrm{N}$ and $\mathrm{P}$ are available, and AM fungi will not benefit seedling establishment where $\mathrm{N}$ and $\mathrm{P}$ are either not available or conversely, where $\mathrm{P}$ is high.

Seedlings of jarrah forest species exhibited a range of responses to applied $\mathrm{N}$ and $\mathrm{P}$, which potentially explain field observations in restored jarrah forest. In particular, the unresponsiveness to fertiliser addition of the cluster-root forming species and slow growing species such as $X$. gracilis suggests that, where fertiliser is applied to restored sites, seedlings of these species will be susceptible to competition from more P-responsive species. In addition, the reduction in growth of a range of the AM species when $\mathrm{P}$ was applied, without additional $\mathrm{N}$, merits further investigation as it may negatively impact seedling establishment. Consequently, our results imply that applying little or no P-fertiliser may be optimal for the return of species belonging to these groups and their mycorrhizas. Increased knowledge of belowground communities and their linkages to aboveground processes, particularly during the critical phase of seedling establishment, may lead to more sophisticated tools for ecosystem restoration (Harris 2009). 
Acknowledgements This research was funded by the Australian Research Council, Alcoa of Australia Ltd and BHP Billiton Worsley Alumina Pty Ltd (ARC Linkage Project 668931). The completion of this work was supported by the Building Outstanding Impact Support Programme H\&F38: Restoring biodiversity to phosphorus sensitive forests and Research England Grant: Policy change to halt biodiversity loss and restore sustainable ecosystems after mining. We are grateful to TD Lardner, B Sadeghzadeh, TL Edmonds-Tibbett, JM Greatrex, EL Walker, BA Stokes, EL Cromer and TL Luitingh for assistance with this research.

Authors' contributions RJS, TKM, JMK, RJH and MT designed the experiment; RJS and TKM established and maintained the experiment; MID, JS and RJS analysed the data; RJS and MID drafted the manuscript, and all the authors contributed to the final draft.

Funding This research was funded by the Australian Research Council, Alcoa of Australia Ltd and BHP Billiton Worsley Alumina Pty Ltd (ARC Linkage Project 668,931). The completion of this work was supported by the Building Outstanding Impact Support Programme H\&F38: Restoring biodiversity to phosphorus sensitive forests and Research England Grant: Policy change to halt biodiversity loss and restore sustainable ecosystems after mining.

Data availability The raw data are available on request to the corresponding author.

\section{Code availability Not applicable.}

\section{Declarations}

Conflicts of interest/competing interests The authors have no conflicts of interest or competing interests to declare.

Open Access This article is licensed under a Creative Commons Attribution 4.0 International License, which permits use, sharing, adaptation, distribution and reproduction in any medium or format, as long as you give appropriate credit to the original author(s) and the source, provide a link to the Creative Commons licence, and indicate if changes were made. The images or other third party material in this article are included in the article's Creative Commons licence, unless indicated otherwise in a credit line to the material. If material is not included in the article's Creative Commons licence and your intended use is not permitted by statutory regulation or exceeds the permitted use, you will need to obtain permission directly from the copyright holder. To view a copy of this licence, visit http://creativecommons.org/licenses/by/4.0/.

\section{References}

Addison SL, Smaill SJ, Garrett LG, Wakelin SA (2019) Effects of forest harvest and fertiliser amendment on soil biodiversity and function can persist for decades. Soil Biol Biochem 135:194-205. https://doi.org/10.1016/j.soilbio.2019.05.006
Allen DG, Jeffery RC (1990) Methods of analysis of phosphorus in Western Australian soils. Report of Investigation No. 37, Chemistry Centre, East Perth, Australia

Allsopp N, Stock WD (1995) Relationships between seed reserves, seedling growth and mycorrhizal responses in 14 related shrubs (Rosidae) from a low-nutrient environment. Funct Ecol 9:248-254. https://doi.org/10.2307/ 2390571

Amazonas NT, Martinelli LA, de Cássia PM, Rodrigues RR (2011) Nitrogen dynamics during ecosystem development in tropical forest restoration. For Ecol Manage 262:1551-1557. https://doi.org/10.1016/j.foreco.2011.07. 003

Banning NC, Grant CD, Jones DL, Murphy DV (2008) Recovery of soil organic matter, organic matter turnover and nitrogen cycling in a post-mining forest rehabilitation chronosequence. Soil Biol Biochem 40:2021-2031. https://doi.org/10.1016/j.soilbio.2008.04.010

Barrow NJ (1977) Phosphorus uptake and utilization by tree seedlings. Aust J Bot 25:571-584. https://doi.org/10. 1071/BT9770571

Bell DT, Plummer JA, Taylor SK (1993) Seed germination ecology in southwestern Western Australia. Bot Rev 59:24-73. https://doi.org/10.1007/BF02856612

Bizuti DT, de Marchi Soares T, Duarte MM, Casagrande JC, de Souza Moreno V, Peinado FJ, Sartorio de Medeiros SD, van Melis J, Schweizer D, Brancalion PH. (2020). Recovery of soil phosphorus on former bauxite mines through tropical forest restoration. Restoration Ecology, 28(5), 1237-1246.

Bolan NS, Robson AD, Barrow NJ (1983) Plant and soil factors including mycorrhizal infection causing sigmoidal response of plants to applied phosphorus. Plant Soil 73:187-201. https://doi.org/10.1007/BF02197715

Bolland MDA, Russell WK (2010) Changes in chemical properties of 48 intensively grazed, rain-fed dairy paddocks on sandy soils over 11 years of liming in southwestern Australia. Soil Research 48:682-692. https:// doi.org/10.1071/SR09199

Bolland MDA, Windsor DP (2007) Converting reactive iron, reactive aluminium, and phosphorus retention index (PRI) to the phosphorus buffering index (PBI) for sandy soils of south-western Australia. Soil Research 45:262265. https://doi.org/10.1071/SR07026

Bowen GD (1981) Coping with low nutrients. In: Pate JS, McComb AJ (eds) The Biology of Australian Plants. The University of Western Australia Press, Nedlands, pp 33-64

Bradshaw AD (1997) The importance of soil ecology in restoration science. In: Urbankska KM, Webb NR, Edwards PJ (eds) Restoration ecology and sustainable development. Cambridge University Press, Cambridge, pp 33-64

Brundrett MC, Abbott LK (1991) Roots of jarrah forest plants. I. Mycorrhizal associations of shrubs and herbaceous plants. Aust J Bot 39:445-457. https://doi.org/10. 1071/BT9910445

Brundrett MC, Abbott LK (1994) Mycorrhizal fungus propagules in the jarrah forest. 1. Seasonal study of inoculum levels. New Phytol 127:539-546. https://doi.org/10. 1111/j.1469-8137.1994.tb03972.x 
Cavagnaro TR, Smith FA, Lorimer MF, Haskard KA, Ayling SM, Smith SE (2001) Quantitative development of Paris-type arbuscular mycorrhizas formed between Asphodelusfistulosus and Glomuscoronatum. New Phytol 149:105-113. https://doi.org/10.1046/j.1469-8137.2001. 00001.x

Chagnon PL, Bradley RL, Maherali H, Klironomos JN (2013) A trait-based framework to understand life history of mycorrhizal fungi. Trends Plant Sci 18:484-491. https://doi. org/10.1016/j.tplants.2013.05.001

Chapin FS III (1980) The mineral nutrition of wild plants. Annu Rev Ecol Syst 11:233-260. https://doi.org/10.1146/ annurev.es.11.110180.001313

Daws MI, Richardson C (2015) An operational scale assessment of the effects of a reduction in fertiliser application rates on plant species responses in jarrah forest restored after bauxite mining. Alcoa of Australia Ltd, Research Note No. 38

Daws MI, Grigg AH, Standish TM, RJ, (2019a) Enduring effects of large legumes and phosphorus fertiliser on jarrah forest restoration 15 years after bauxite mining. For Ecol Manage 438:204-214. https://doi.org/10.1016/j. foreco.2019.02.029

Daws MI, Grigg AH, Standish, R.J, Tibbett M (2019b) Applied phosphorus has long-term impacts on vegetation responses in restored jarrah forest, In: Fourie AB, Tibbett M (eds) Proceedings of the 13th international conference on mine closure. Australian Centre for Geomechanics, Perth, Australia pp 693-704. https://doi.org/10.36487/ ACG_rep/1915_55

Daws MI, Standish RJ, Koch JM, Morald TK (2013) Nitrogen and phosphorus fertiliser regime affect jarrah forest restoration after bauxite mining in Western Australia. Appl Veg Sci 16:610-618. https://doi.org/10.1111/avsc. 12046

de Campos MCR, Pearse SJ, Oliveira RS, Lambers H (2013) Downregulation of net phosphorus-uptake capacity is inversely related to leaf phosphorus-resorption proficiency in four species from a phosphorus-impoverished environment. Ann Bot 111:445-454. https://doi.org/10.1093/aob/ $\operatorname{mcs} 299$

Dell B, Jones S, Wilson SA (1987) Phosphorus nutrition of jarrah (Eucalyptus marginata) seedlings. Plant Soil 97:369379. https://doi.org/10.1007/BF02383227

Elston DA (1998) Estimation of denominator degrees of freedom of F-distributions for assessing Wald statistics for fixed-effect factors in unbalanced mixed models. Biometrics 54:1085-1096. https://doi.org/10.2307/2533859

Galwey NW (2006) Introduction to Mixed Modelling: Beyond Regression and Analysis of Variance, 1st edition. John Wiley and Sons Ltd, Chichester, UK.

George SJ, Tibbett M, Braimbridge MF, Davis SG, Vlahos S, Ryan M (2006) Phosphorus fertiliser placement and seedling success in Australian jarrah forest. In: Fourie A, Tibbett M (eds) Proceedings of the first international seminar on mine closure, Australian Centre for Geomechanics, Perth Australia, pp 341-349. https://doi.org/10.36487/ ACG_repo/605_27

Gerdemann JW (1975) Vesicular-arbuscular mycorrhizae. In: Torrey JG, Clarkson DT (eds) The development and function of roots. Academic Press, New York, pp 575-591
Giovanetti M, Mosse B (1980) An evaluation of techniques for measuring VAM infection in roots. New Phytologist 84:489-500. https://www.jstor.org/stable/2432123

Grant CD (2006) State-and-transition successional model for bauxite mining rehabilitation in the jarrah forest of Western Australia. Restor Ecol 14:28-37. https://doi.org/10. 1111/j.1526-100X.2006.00102.x

Handreck KA (1997) Phosphorus requirements of Australian native plants. Aust J Soil Res 35:241-289. https://doi.org/ 10.1071/S96060

Handreck KA (1991) Interactions between iron and phosphorus in the nutrition of Banksiaericifolia L. f. var. ericifolia (Proteaceae) in soil-less potting media. Aust J Bot 39:373-384. https://doi.org/10.1071/BT9910373

Harris JA (2009) Soil microbial communities and restoration ecology: facilitators or followers? Science 325:573-574. https://doi.org/10.1126/science. 1172975

Holmes PM (2001) Shrubland restoration following woody alien invasion and mining: effects of topsoil depth, seed source, and fertilizer addition. Restor Ecol 9:71-84. https://doi.org/10.1046/j.1526-100x.2001.009001071.x

Huang CY, Shirley N, Genc Y, Shi S, Langridge P (2011) Phosphate utilization efficiency correlates with expression of low-affinity phosphate transporters and noncoding RNA, IPS1, in barley. Plant Physiol 156:1217-1229. https://doi.org/10.1104/pp.111.178459

Jasper DA (2007) Beneficial soil microorganisms of the jarrah forest and their recovery in bauxite mine restoration in southwestern Australia. Restor Ecol 15:S74-S84. https:// doi.org/10.1111/j.1526-100X.2007.00295.x

Jasper DA, Abbott LK, Robson AD (1989) Acacias respond to additions of phosphorus and to inoculation with VA mycorrhizal fungi in soils stockpiled during mineral sand mining. Plant Soil 115:99-108. https://doi.org/10.1007/BF02220699

Johnson NC (2010) Resource stoichiometry elucidates the structure and function of arbuscular mycorrhizas across scales. New Phytol 185:631-647. https://doi.org/10. 1111/j.1469-8137.2009.03110.x

Johnson NC, Graham JH, Smith FA (1997) Functioning of mycorrhizal associations along the mutualism-parasitism continuum. New Phytol 135:575-585. https://doi.org/10. 1046/j.1469-8137.1997.00729.x

Johnson NC, Wilson GWT, Bowker MA, Wilson JA, Miller RM (2010) Resource limitation is a driver of local adaptation in mycorrhizal symbioses. Proc Natl Acad Sci 107:2093-2098. https://doi.org/10.1073/pnas.0906710107

Kariman K, Barker SJ, Finnegan PM, Tibbett M (2014) Ectoand arbuscular mycorrhizal symbiosis can induce tolerance to toxic pulses of phosphorus in jarrah (Eucalyptus marginata) seedlings. Mycorrhiza 24:501-509. https:// doi.org/10.1007/s00572-014-0567-6

Koch JM (2007) Alcoa's mining and restoration process in south Western Australia. Restor Ecol 15:S11-S16. https:// doi.org/10.1111/j.1526-100X.2007.00288.x

Koch JM, Hobbs RJ (2007) Synthesis: is Alcoa successfully restoring a jarrah forest ecosystem after bauxite mining in Western Australia? Restor Ecol 15:S137-S144. https:// doi.org/10.1111/j.1526-100X.2007.00301.x

Lambers H, Juniper D, Cawthray GR, Veneklaas EJ, MartínezFerri E (2002) The pattern of carboxylate exudation in Banksiagrandis (Proteaceae) is affected by the form of 
phosphate added to the soil. Plant Soil 238:111-122. https://doi.org/10.1023/A:1014289121672

Lambers H, Raven JA, Shaver GR, Smith SE (2008) Plant nutrient-acquisition strategies change with soil age. Trends Ecol Evol 23:95-103. https://doi.org/10.1016/j. tree.2007.10.008

Lamont BB (1972a) The effect of soil nutrients on the production of proteoid roots by Hakea species. Aust J Bot 20:2740. https://doi.org/10.1071/BT9720027

Lamont BB (1972b) The morphology and anatomy of proteoid roots in the genus Hakea. Aust J Bot 80:155-174. https:// doi.org/10.1071/BT9720155

Malajczuk N, Bowen GD (1974) Proteoid roots are microbially induced. Nature 251:316-317. https://doi.org/10.1038/ $251316 \mathrm{a} 0$

Mitchell DT, Allsopp N (1984) Changes in the phosphorus composition of seeds of Hakeasericea (Proteaceae) during germination under low phosphorus conditions. New Phytol 96:239-247. https://doi.org/10.1111/j.1469-8137. 1984.tb03560.x

Nazeri NK, Lambers H, Tibbett M, Ryan MH (2014) Moderating mycorrhizas: arbuscular mycorrhizas modify rhizosphere chemistry and maintain plant phosphorus status within narrow boundaries. Plant, Cell Environ 37:911921. https://doi.org/10.1111/pce.12207

Neuenkamp L, Prober SM, Price JN, Zobel M, Standish RJ (2019) Benefits of mycorrhizal inoculation to ecological restoration depend on plant functional type, restoration context and time. Fungal Ecol 40:140-149. https://doi. org/10.1016/j.funeco.2018.05.004

Norman MA, Koch JM, Grant CD, Morald TK, Ward SC (2006) Vegetation succession after bauxite mining in Western Australia. Restor Ecol 14:278-288. https://doi. org/10.1111/j.1526-100X.2006.00130.x

Nussbaumer Y, Cole MA, Offler CE, Patrick JW (2016) Identifying and ameliorating nutrient limitations to reconstructing a forest ecosystem on mined land. Restor Ecol 24:202-211. https://doi.org/10.1111/rec.12294

Pang JY, Tibbett M, Denton MD, Lambers H, Siddique KHM, Bolland MDA, Revell CK, Ryan MH (2010) Variation in seedling growth of 11 perennial legumes in response to phosphorus supply. Plant Soil 328:133-143. https://doi. org/10.1007/s11104-009-0088-9

Pate JS, Froend RH, Bowen BJ, Hansen A, Kuo J (1990) Seedling growth and storage characteristics of seeder and resprouter species of Mediterranean-type ecosystems of SW Australia. Ann Bot 65:585-601. https://doi.org/10. 1093/oxfordjournals.aob.a087976

Payne RW, Harding SA, Murray DA, Soutar DM, Baird DB et al. (2008) GenStat Release 11.1 (PC/ Windows) Copyright. VSN International Ltd, Hertfordshire

Pinno BD, Landhäusser SM, MacKenzie MD, Quideau SA, Chow PS (2012) Trembling aspen seedling establishment, growth and response to fertilization on contrasting soils used in oil sands reclamation. Can J Soil Sci 92:143-151. https://doi.org/10.4141/cjss2011-004

Plenchette C, Fortin JA, Furlan V (1983) Growth response of several plant species to mycorrhizae in a soil of moderate P-fertility I. Mycorrhizal dependency under field conditions. Plant Soil 70:199-209. https://doi.org/10.1007/ BF02374780
Rowland SM, Prescott CE, Grayston SJ, Quideau SA, Bradfield GE (2009) Recreating a functioning forest soil in reclaimed oil sands in northern Alberta: an approach for measuring success in ecological restoration. J Environ Qual 38:1580-1590. https://doi.org/10.2134/jeq2008.0317

Shane MW, Lambers H (2005) Cluster roots: a curiosity in context. Plant Soil 274:101-125. https://doi.org/10.1007/ s11104-004-2725-7

Shane MW, Szota C, Lambers H (2004a) A root trait accounting for the extreme phosphorus sensitivity of Hakeaprostrata (Proteaceae). J Exp Bot 27:991-1004. https://doi. org/10.1111/j.1365-3040.2004.01204.x

Shane MW, McCully ME, Lambers H (2004b) Tissue and cellular phosphorus storage during development of phosphorus toxicity in Hakeaprostrata (Proteaceae). J Exp Bot 55:1033-1044. https://doi.org/10.1093/jxb/ erh 111

Shane MW, Lambers H (2006) Systematic suppression of cluster-root formation and net P-uptake rates in Grevilleacrithmifolia at elevated $\mathrm{P}$ supply: a proteacean with resistance for developing symptoms of 'P toxicity.' J Exp Bot 57:413-423. https://doi.org/10.1093/jxb/erj004

Smits NAC, Willems JH, Bobbink R (2008) Long-term aftereffects of fertilisation on the restoration of calcareous grasslands. Appl Veg Sci 11:279-286. https://doi.org/10. 3170/2008-7-18417

Smith SE, Read DJ (2008) Mycorrhizal symbiosis, 3rd edn. Academic Press, London

Spain AV, Tibbett M, Hinz DA, Ludwig JA, Tongway DJ (2015) The mining-restoration system and ecosystem development following bauxite mining in a biodiverse environment of the seasonally dry tropics, Northern Territory, Australia. In: Tibbett M (ed) Mining in Ecologically Sensitive Landscapes. CRC Press, Netherlands, pp 159-227

Standish RJ, Morald TK, Koch JM, Hobbs RJ, Tibbett M (2008) Restoring jarrah forest after bauxite mining in Western Australia-the effect of fertilizer on floristic diversity and composition. In: Fourie AB, Tibbett M, Weiersbye IM, Dye PJ (eds) Mine Closure 2008. Australian Centre for Geomechanics, Perth, Australia, pp 717725. https://doi.org/10.36487/ACG_repo/852_67

Standish RJ, Daws MI, Gove AD, Didham RK, Grigg AH, Koch JM, Hobbs RJ (2015) Long-term data suggest jarrah-forest establishment at restored mine sites is resistant to climate variability. J Ecol 103:78-89. https://doi.org/10. 1111/1365-2745.12301

Standish RJ, Albornoz F, Morald TK, Hobbs RJ, Tibbett M (2021) Mycorrhizal symbiosis and phosphorus supply determine interactions among plants with contrasting nutrient acquisition strategies. Journal of Ecology, accepted 9 August 2021

Standish RJ, Cramer VA, Hobbs RJ, Kobryn HT (2006) Legacy of land-use evident in soils of Western Australia's wheatbelt. Plant Soil 280:189-207. https://doi.org/10. 1007/s11104-005-2855-6

Stock WD, Pate JS, Delfs J (1990) Influence of seed size and quality on seedling development under low nutrient conditions in five Australian and South African members of the Proteaceae. J Ecol 78:1005-1020. https://doi.org/10.2307/ 2260949 
Stoneman GL, Dell B, Turner NC (1995) Growth of Eucalyptus marginata (jarrah) seedlings in Mediterranean-climate forest in south-west Australia in response to overstorey, site and fertiliser application. For Ecol Manage 79:173184. https://doi.org/10.1016/0378-1127(95)03608-3

Tibbett M (2010) Large-scale mine site restoration of Australian eucalypt forests after bauxite mining: soil management and ecosystem development. In: Batty LC, Hallberg K (eds) Ecology of industrial pollution. Cambridge University Press, Cambridge, pp 309-326

Tibbett M, O'Connor R, Daws MI (2019) Too much of a good thing: phosphorus over-fertilisation in rehabilitated landscapes of high biodiversity value. In: Fourie AB, Tibbett $M$ (eds) Proceedings of the 13th International Conference on Mine Closure. Australian Centre for Geomechanics, Perth, Australia, pp 651-666. https://doi.org/10.36487/ ACG_rep/1915_52

Tibbett M, Daws MI, George SJ, Ryan MH (2020) The where, when and what of phosphorus fertilisation for seedling establishment in a biodiverse jarrah forest restoration after bauxite mining in Western Australia. Ecol Eng 153:105907. https://doi.org/10.1016/j.ecoleng.2020.105907

Tibbett, M., Daws, M. I., \& Ryan, M. H. (2021). Phosphorus uptake and toxicity is delimited by mycorrhizal symbiosis in P-sensitive Eucalyptus marginata but not in $\mathrm{P}$ tolerant Acacia celastrifolia. bioRxiv.

United Nations Sustainable Development Goals (2015) Transforming our world: the 2030 Agenda for Sustainable Development. Agenda adopted by the 193 Member States of the United Nations in New York on 25 September 2015. Available at https://sustainabledevelopment.un.org/ post2015/transformingourworld/publication (accessed 20 April 2021).
Walker C (2005) A simple blue staining technique for arbuscular mycorrhizal and other root-inhabiting fungi. Inoculum 56:68-69

Ward SC, Koch JM, Nichols OG (1990) Bauxite mine rehabilitation in the Darling Range, Western Australia. Proc Ecol Soc Aust 16:557-565

Wassen MJ, Venterink HO, Lapshina ED, Tanneberger F (2005) Endangered plants persist under phosphorus limitation. Nature 437:547-550. https://doi.org/10.1038/ s41559-020-01323-w

Western Australian Herbarium. 1998-. FloraBase — The Western Australian Flora. Department of Environment and Conservation, Perth, Western Australia. Available at http://florabase.dec.wa.gov.au/ (Accessed 31 March 2010).

Whisenant SG (1999) Repairing damaged wildlands: a process-orientated, landscape-scale approach. Cambridge University Press, Cambridge

Williams A, George S, Birt H, Daws MI, Tibbett M (2019) Sensitivity of seedling growth to phosphorus supply in six tree species of the Australian Great Western Woodlands. Aust J Bot 67:390-396. https://doi.org/10.1071/BT18247

Zarcinas BA (1984) Analysis of soil and plant material by inductively coupled plasma-optical spectrometry: comparison of digestion procedures for major and trace constituents in plant material. CSIRO Division of Soils Divisional Report No 70, Canberra

Publisher's note Springer Nature remains neutral with regard to jurisdictional claims in published maps and institutional affiliations. 